DEPARTAMENTO DE ENGENHARIA MECÂNICA

Pós-Graduação em Engenharia de Dutos

Estudo de Caso Sobre as Melhorias Obtidas Com a Implantação do SAP PM no Processo de Detecção de Escapamento de Gás Natural

Flavio Monteiro da Silva Coutinho

José Luiz de França Freire 
Flavio Monteiro da Silva Coutinho

\section{Estudo de Caso Sobre as Melhorias Obtidas Com a Implantação do SAP PM no Processo de Detecção de Escapamento de Gás Natural}

Monografia APRESENTAdA Ao Programa de Pós-GRAduAÇÃo EM ENGENHARIA MECÂNICA DA PUC-RIO COMO REQUISITO PARCIAL PARA OBTENÇÃO DO TÍTULO DE ESPECIALISTA EM ENGENHARIA DE DUTOS. APROVADA PELA COMISSÃO EXAMINADORA ABAIXO ASSINADA.

Orientador: Professor José Luiz de França Freire Co-orientador: Eng. Placido Pino Heredia Marins

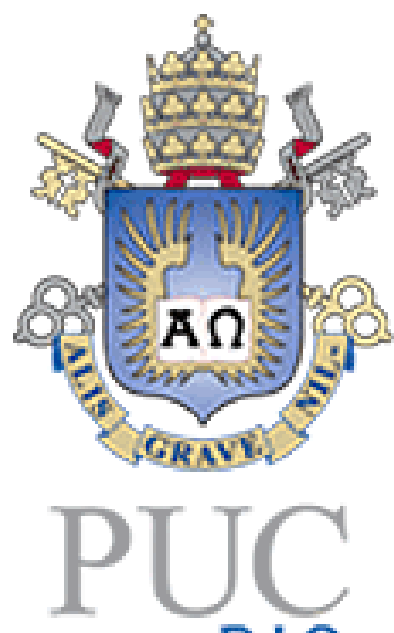

R IO

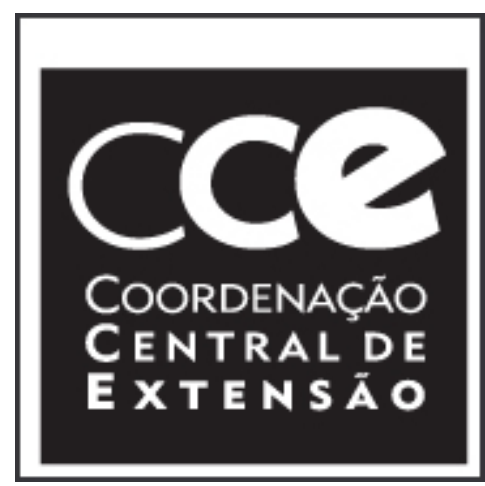

Rio de Janeiro 20 de Dezembro 2018 


\section{AGRADECIMENTOS}

Primeiramente agradeço a Deus por me propiciar a realização do presente trabalho.

Em especial ao Professor Prof. José Luiz Feire, pela dedicação, lições e aprendizados.

A todo o corpo docente do curso de engenharia de dutos da PUCRIO, que nos propiciou um curso pós-graduação de qualidade no mercado de trabalho, com professores altamente qualificados no segmento.

Também quero agradecer a minha esposa Débora Telles, que sempre me incentivou a concluir esse trabalho, me apoiando e dando forças todos os dias, nos momentos bons ou difíceis, e principalmente fazendo com que meu objetivo fosse alcançado de maneira mais sólida e eficiente.

Por fim ao meu Co-orientador Eng. Placido Pino, pelas dicas, orientações e ensinamentos. 


\section{RESUMO}

O intuito deste estudo é apresentar os principais impactos após a implantação do sistema da informação SAP PM, exclusivamente no processo de detecção de escapamento de gás em uma empresa distribuidora de gás natural. O sistema de distribuição de gás natural é composto por uma grande rede de gasodutos enterrados formada por milhares de quilômetros e milhares de equipamentos auxiliares que necessitam estar em condições aptas a operar.

Foram criados os cadastros dos equipamentos, planos de manutenção, mapeamentos e padronizações de todos os equipamentos no sistema computacional para controle individual, pois, por se tratar de uma distribuidora de gás natural, os aspectos de segurança vêm em primeiro plano devido ao elevado grau de risco característico.

Diante desse estudo, surtiram resultados extremamente positivos: melhorias nos processos de controle, simplificação na execução das atividades e crescimento na confiabilidade das informações. Concluiu-se que o impacto gerado pelo novo sistema trouxe aspectos positivos evidenciados na grande melhoria do processo de gestão da manutenção

Palavras-chave: Gás natural, Escapamento e SAP PM. 


\section{SUMÁRIO}

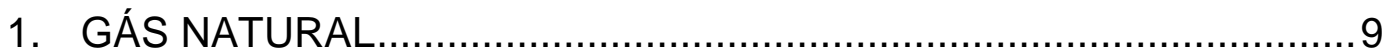

2. EQUIPAMENTOS DO SISTEMA DE DISTRIBUIÇÃO DE GÁS

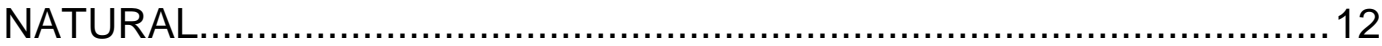

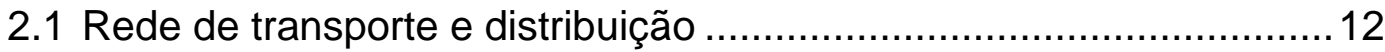

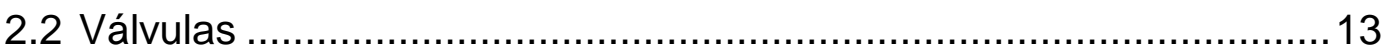

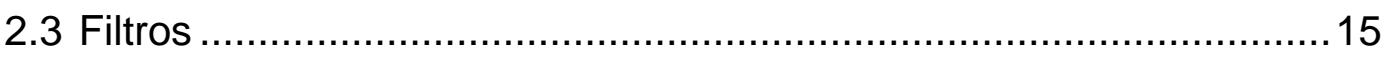

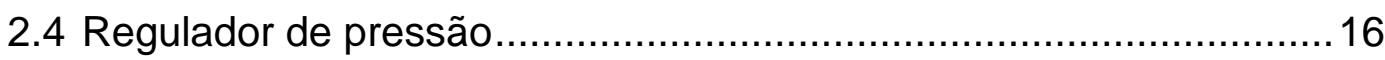

2.5 Estação reguladora de pressão (ERP) ………….......................... 18

2.6 Sistema de proteção catódica....................................................19

3. MANUTENÇÃO: FUNDAMENTAÇÃO TEÓRICA …..........................20

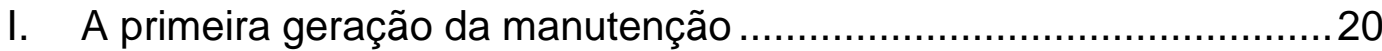

II. A segunda geração da manutenção .............................................20

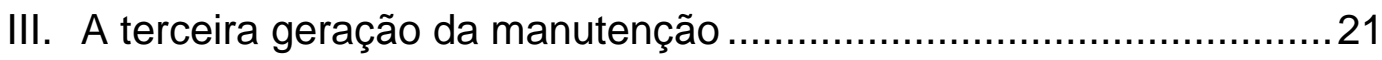

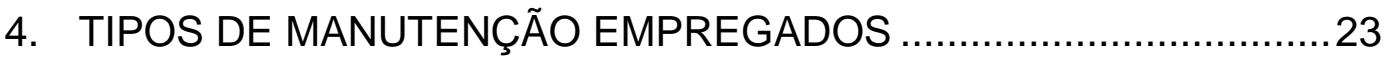

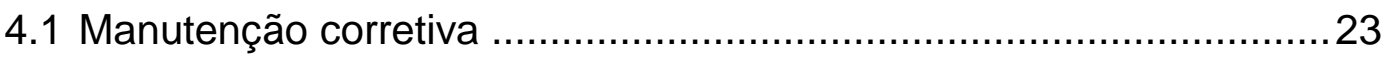

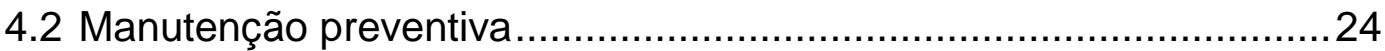

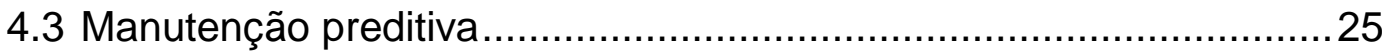

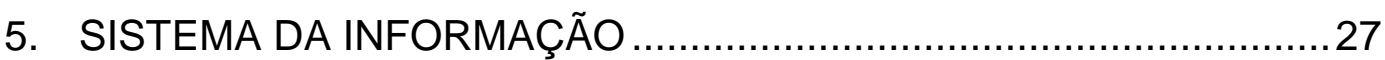

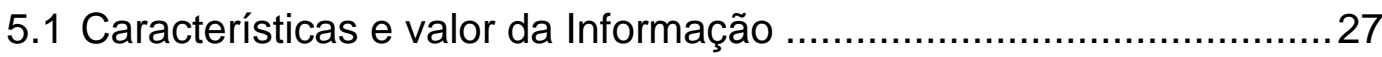

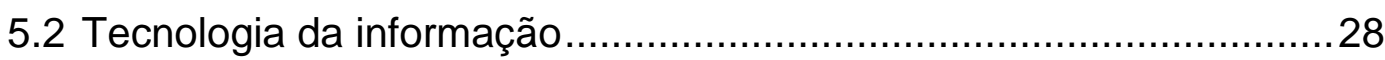

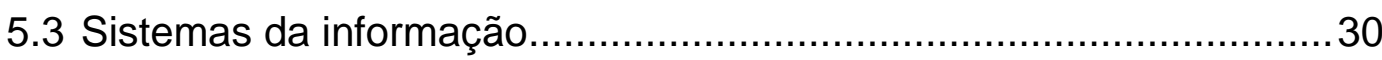

5.4 Sistemas da informação integrados de gestão ..................................31

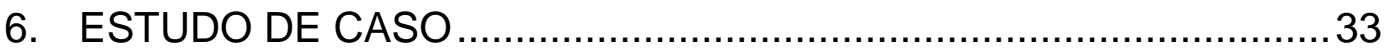

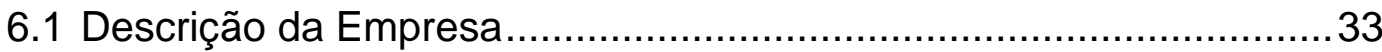

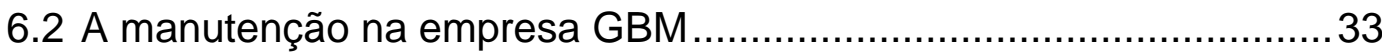

6.3 Estrutura organizacional da manutenção .........................................34

6.4 Fluxo do processo da manutenção na GBM ...................................34

6.5 Gerenciamento da manutenção ERP SAP R3 - Módulo PM..............35

6.6 Descrição da estrutura hierárquica do SAP PM ...............................37

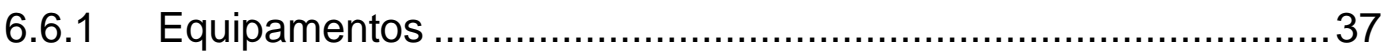

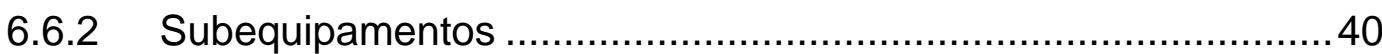

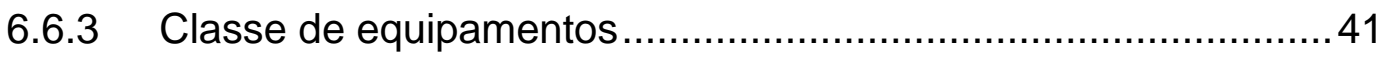

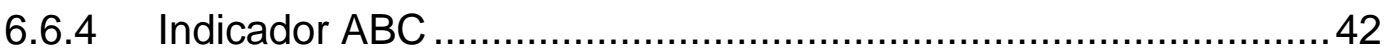

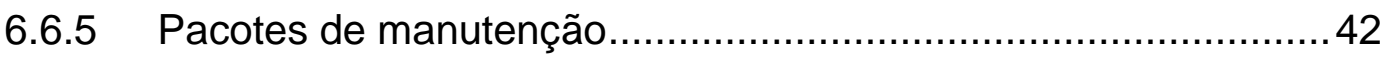

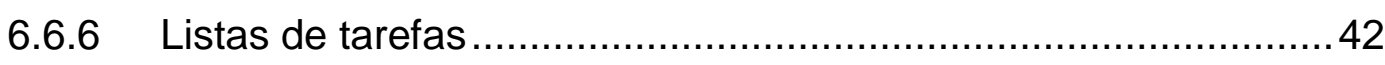

6.6.7 Planos de manutenção preventiva ............................................ 43

6.7 Processo de detecção de escapamento de gás natural .....................43 
6.7.1 Gestão da manutenção do processo de detecção de gás natural antes da implantação do sistema SAP PM............................................4 44

6.7.2 Gestão da manutenção do processo de detecção de gás após

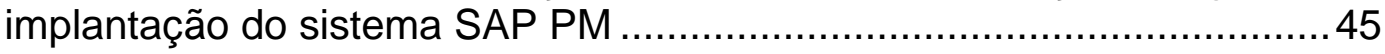

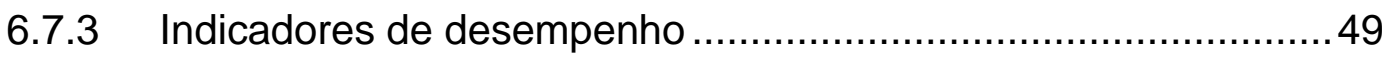

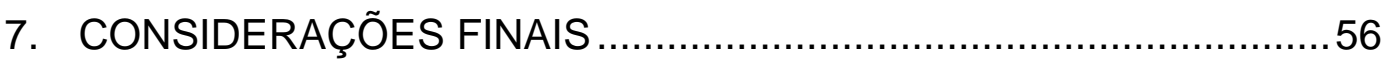

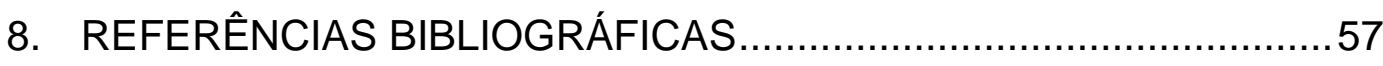




\section{LISTA DE FIGURAS}

Figura 1 - Válvula de bloqueio de rede, com acionamento manual ..........14

Figura 2 - Esquema básico de filtragem do gás .....................................14

Figura 3 - Exemplos de filtro tipo cartucho ...........................................15

Figura 4 - Esquema didático de um regulador de ação direta ...................14

Figura 5 - Esquema didático de um regulador de ação pilotado ...............14 14

Figura 6 - Estação reguladora de gás ………….................................. 18

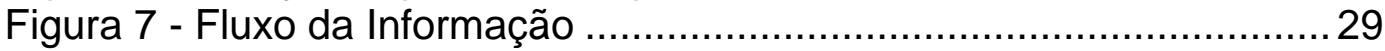

Figura 8 - Evolução de clientes nos últimos 5 anos ............................... 32

Figura 09 - Custo com Manutenção ……………................................. 34

Figura 10 - Estrutura organizacional da Manutenção ................................34

Figura 11 - Diagrama de fluxo da Manutenção ……………………........ 35

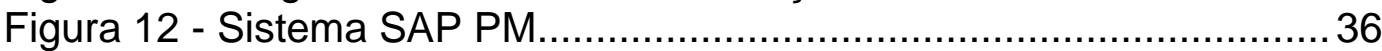

Figura 13 - Descrição da estrutura hierárquica do SAP PM …..................37

Figura 14 - Dados gerais do cadastro do equipamento..............................38

Figura 15 - Status do equipamento ................................................... 39

Figura 16 - Lista de estrutura de subequipamentos ..............................4 40

Figura 17 - Classe de equipamento ................................................ 41

Figura 18 - Pacotes de manutenção ................................................. 42

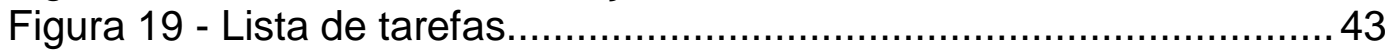

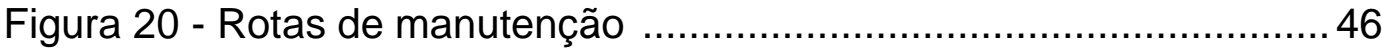

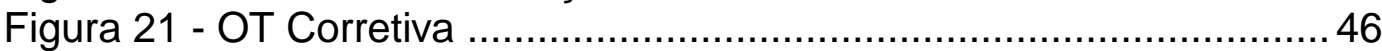

Figura 22 - Lista da situação atual das ordens .....................................48 48

Figura 23 - Projeção do plano de manutenção ...................................... 49

Figura 24 - Lista dos dados tabulados das fugas ................................50

Figura 25 - Quantidade de fugas detectadas por mês na rede Leste I ....52

Figura 26 - Quantidade de fugas detectadas por mês na rede Leste II ...52

Figura 27 - Quantidade de fugas detectadas por mês na rede Oeste .....53

Figura 28 - Quantidade de fugas detectadas por mês na rede Norte I.....53

Figura 29 - Quantidade de fugas detectadas por mês na rede Norte II ...54

Figura 30 - Quantidade de fugas detectadas no período de 36 meses ...55 


\section{LISTA DE TABELAS}

Tabela 1 - Composição química do gás natural .......................................

Tabela 2 - Comparação entre emissões de $\mathrm{NO}_{\times} \mathrm{CO}_{2}$ e $\mathrm{CO}$......................11

Tabela 3 - Evolução da manutenção ...................................................21

Tabela 4 - Boas práticas de manutenção ..............................................22

Tabela 5 - Características da Informação I..........................................2 27

Tabela 6 - Características da Informação II..........................................28

Tabela 7 - As revoluções da Informação ..............................................29

Tabela 8 - Transações básicas do SAP PM ........................................ 36

Tabela 9 - NF/km.Ano no período entre 01/09/2015 e 30/08/2016 ..........50

Tabela 10 - NF/km.Ano no período entre 01/09/2016 e 30/08/2017 ........51

Tabela 11 - NF/km.Ano no período entre 01/09/2017 e 30/08/2018 .......51

Tabela 12 - NF/km.Ano no período entre 01/09/2015 e 30/08/2018........54

Tabela 13 - Custo de localização e reparação de fugas na rede..............55 


\section{LISTA DE ABREVIATURAS E SIGLAS}
ABNT
Associação Brasileira de Normas Técnicas
ERP
Estação Reguladora de Pressão
MPO
Máxima Pressão de Operação, expressa em bar
$\mathrm{NF} / \mathrm{km}$.Ano
Número de Fugas por Quilômetro de Rede Detectada
OT
Ordem de Trabalho
PEAD
Polietileno de Alta Densidade 


\section{GÁS NATURAL}

O gás natural é um combustível fóssil, composto basicamente por uma mistura de hidrocarbonetos leves, normalmente encontrado na natureza acumulado em rochas porosas, podendo estar associado ou não ao petróleo, isolado por rochas impermeáveis do exterior. Ele é o resultado da degradação da matéria orgânica na forma anaeróbica oriunda de quantidades extraordinárias de microrganismos que, em eras pré-históricas, se acumulavam nas águas litorâneas dos mares da época. Essa matéria orgânica foi soterrada a grandes profundidades e, por isto, sua degradação se deu fora do contato com o ar, a grandes temperaturas e sob fortes pressões. [1]

Na tabela abaixo podemos observar a composição típica do gás natural:

Tabela 1 - Composição química do gás natural

\begin{tabular}{|c|c|}
\hline Composto químico & Volume em percentual (\%) \\
\hline Metano & 89,00 \\
\hline Propano & 6,0 \\
\hline Butano & 1,80 \\
\hline $\mathrm{C} 4+$ & 1,0 \\
\hline $\mathrm{CO}_{2}$ & 1,5 \\
\hline $\mathrm{N}_{2}$ & 0,7 \\
\hline
\end{tabular}

Fonte: Monteiro, 2010.

De acordo com a Lei n. 9478/97, o gás natural é definido como:

Gás natural é a porção do petróleo que existe na fase gasosa ou em solução no óleo, nas condições originais do reservatório, o que permanece no estado gasoso nas condições atmosféricas de pressão e temperatura.

O gás natural é inodoro, mas, por questões de segurança, ele é odorizado artificialmente, assim a sua presença pode ser facilmente detectável por qualquer pessoa. A odoração do gás é feita por adição em pequenas quantidades de mistura à base de mercaptanas, constituídas de componentes como o tercbutilmercaptana, o isopropilmercaptana, o N-proprilmercaptana etc.[1]

Segundo a ABNT 12712 (2002, p. 55): 
Todo gás combustível deve ser odorizado em redes de distribuição e serviço ou para uso doméstico, de modo a permitir, em caso de vazamento, a sua pronta detecção em limites de concentração a partir de $1 / 5$ de seu limite de explosividade inferior.

O gás natural é composto basicamente de metano, uma molécula de carbono e quatro de hidrogênio. Quando o processo de combustão é perfeito, os subprodutos gerados na queima são o vapor de água e dióxido de carbono, produzindo considerável quantidade de energia.

Os demais combustíveis fósseis, como o óleo diesel e os compostos de carvão, possuem estruturas moleculares muito mais complexas, com altas taxas de carbono, bem como diversos compostos de enxofre e nitrogênio. Em decorrência não produzem uma queima tão limpa, além de liberarem partículas de cinza, que não queimam completamente e são carregadas para a atmosfera.

Ao contrário destes, o gás natural é considerado um combustível limpo. Ele emite a menor taxa de dióxido de carbono $\left(\mathrm{CO}_{2}\right)$ quando queimado, liberando na atmosfera baixos teores de subprodutos perigosos ao meio ambiente que contribuem para o efeito estufa [1].

Sendo assim, sobre os aspectos ambientais, o gás natural é muito superior aos outros combustíveis fósseis, por isso seu consumo pode ser encarado como uma efetiva contribuição ao controle da poluição ambiental. [1]

A utilização do gás natural pode ajudar na manutenção da qualidade do ar e da água, principalmente quando substitui outras fontes de energia mais poluentes. Conforme podemos observar na tabela 2, as emissões de $\mathrm{CO}$ e $\mathrm{CO}_{2}$ são inferiores quando comparados ao carvão mineral e ao óleo combustível. Quando aplicado na indústria de cimento, é 4 vezes menor a emissão de $\mathrm{CO}_{2}$ em relação ao óleo combustível e ao carvão mineral. Por essas razões, o gás natural é considerado o combustível do século XXI [1].

Segundo Monteiro (2010, p. 34):

A capacidade do gás natural em reduzir emissões indesejáveis é tão grande que a cidade de Cubatão no estado de São Paulo, no litoral Paulista, só está conseguindo se tornar habitável porque $90 \%$ das numerosas indústrias instaladas fizeram conversão para o gás natural, abandonando o uso de óleos pesados de refinarias. 
Tabela 2 - Comparação entre emissões de $\mathrm{NO}_{\times} \mathrm{CO}_{2}$ e $\mathrm{CO}$

\begin{tabular}{|c|c|c|c|c|c|c|c|c|c|c|}
\hline Aplicação & \multirow{2}{*}{$\begin{array}{c}\text { Processamento / } \\
\text { Equipamento }\end{array}$} & \multicolumn{3}{|c|}{ Carvão mineral } & \multicolumn{3}{|c|}{ Óleo combustível } & \multicolumn{3}{|c|}{ Gás Natural } \\
\hline \multirow{3}{*}{ Indústria } & & $\mathrm{NO}_{\mathrm{x}}$ & $\mathrm{CO}$ & $\mathrm{CO}_{2}$ & $\mathrm{NO}_{\mathrm{x}}$ & $\mathrm{CO}$ & $\mathrm{CO} 2$ & $\mathrm{NO}_{\mathrm{x}}$ & $\mathrm{CO}$ & $\mathrm{CO}_{2}$ \\
\hline & Cimento & 455 & 70 & 219.200 & 535 & 80 & $\begin{array}{c}203.10 \\
0\end{array}$ & 1.050 & 80 & 56.100 \\
\hline & $\begin{array}{c}\text { Curtume, } \\
\text { alimentos, } \\
\text { bebidas e papel }\end{array}$ & 280 & 155 & 94.200 & 165 & 15 & 73.800 & 65 & 15 & 56.100 \\
\hline \multirow{5}{*}{ Termoelétrica } & $\begin{array}{c}\text { Carvão } \\
\text { pulverizado }\end{array}$ & 740 & 10 & 94.200 & - & - & - & - & - & - \\
\hline & Leito fluidizado & 740 & 10 & 94.200 & - & - & - & - & - & - \\
\hline & Caldeiras & & & 94.200 & 205 & 15 & 73.800 & 250 & 20 & 56.100 \\
\hline & Ciclo combinado & & & 94.200 & & & & 250 & 20 & 56.100 \\
\hline & Ciclo Simples & & & 94.200 & & & & 250 & 20 & 56.100 \\
\hline
\end{tabular}

Fonte: Monteiro, 2010. 


\section{EQUIPAMENTOS DO SISTEMA DE DISTRIBUIÇÃO DE GÁS NATURAL}

No Brasil, o gás natural é comercializado por meios de contratos de fornecimento com empresas distribuidoras, possuidoras da concessão de distribuição. As empresas distribuidoras recebem o gás natural proveniente das empresas transportadoras nas estações de transferência de custódia (city gates), também conhecidas como pontos de entrega, que são instalações responsáveis por rebaixar a pressão do gás natural dentro das especificações de distribuição e realizar a sua medição de volume entregue à concessionária. Neste momento é feita a odoração do gás. Os principais elementos do sistema de distribuição são:

\subsection{Rede de transporte e distribuição}

As redes de transporte e distribuição de gás natural são compostas por basicamente gasodutos enterrados, responsáveis pela condução do gás de forma segura desde as estações de transferência de custódia até o cliente final. Os gasodutos são compostos por tubulações interconectadas entre si por meio de processo de soldagem metálica ou termofusão. Atualmente existem dois tipos de materiais para a fabricação: aço carbono, para pressões de operação superiores a 7 bar, e em polietileno de alta densidade, para pressões de trabalho igual ou inferiores 7 bar. [1]

Os gasodutos em aço carbono são aplicados tanto para transporte entre as estações de transferências de custódia (city gate) até as estações redutoras de pressão (ERP), para pressões de operação superiores a 7 bar, quanto para distribuição com pressões de operação iguais ou inferiores a 7 bar. São instalados diretamente no solo, em valas, a uma profundidade média de $1,5 \mathrm{~m}$ em relação ao terreno local. [1]

Os gasodutos em aço carbono são estruturas que estão submetidas a corrosão pelo solo. Por esse motivo são revestidos externamente por meio de materiais poliméricos ou betuminosos de alta espessura, que são aplicados sobre a superfície metálica, provendo uma barreira entre o metal e o meio corrosivo. Existem diversos tipos de revestimento; os mais empregados atualmente são: asfálticos, plásticos, revestimentos por tinta à base de cooltar - epóxi, polietileno ou polipropileno extrudado. [5] 
Os gasodutos em polietileno alta densidade (PEAD) são utilizados para redes de distribuição de gás natural normalmente em ambiente urbano. São encontrados nos diâmetros de PE80 e PE100 e fazem a interligação entre as ERP (estações redutoras de pressão) e o cliente final. São instalados diretamente no solo em valas a uma profundidade média de 0,6 m em relação ao terreno local. [1]

Por ter baixo custo de instalação em comparação aos gasodutos de aço carbono e fácil manutenção, o mercado das tubulações em PEAD vem crescendo continuamente desde os anos 80 . Este recurso vem sendo utilizado em grande escala pelas distribuidoras de gás natural no Brasil, com notável melhoria no material em si e também no seu desempenho, apresentando maior expectativa de vida útil, maior resistência mecânica e consequentemente maior resistência à pressão. [4]

\subsection{Válvulas}

As válvulas são elementos ou dispositivos destinados a estabelecer, controlar e interromper o fornecimento do fluxo. São os acessórios mais importantes das tubulações, por isso requerem o maior cuidado quanto à sua especificação, quantidade e localização. As tubulações devem possuir o menor número de válvulas possível, porque são peças caras e podem apresentar vazamentos, além de gerar perda de carga. [7]

Contudo, as válvulas são peças indispensáveis, pois sem elas as tubulações seriam praticamente inúteis. A localização das válvulas deve ser analisada com cuidado para que a operação e manutenção sejam fáceis e rápidas. Existe uma grande diversidade de válvulas para vários tipos de aplicação. [7]

I. Válvulas de bloqueio: destinadas exclusivamente para estabelecer ou interromper o fluxo, são projetadas para operar totalmente abertas ou totalmente fechadas. Elas têm normalmente o mesmo diâmetro nominal das tubulações em que estão instaladas e são encontradas nos seguintes tipos:

- Válvulas gaveta;

- Válvulas macho;

- Válvulas esfera; e

- Válvulas comporta.

II. Válvulas de regulagem: destinadas exclusivamente para controlar o fluxo, podem operar em qualquer posição de fechamento ou abertura parcial. Por 
motivos de economia, possuem diâmetro nominal menor do que a tubulação e são encontradas nos seguintes tipos:

- $\quad$ Válvulas de globo;

- Válvulas de agulha;

- Válvulas de controle;

- Válvulas de borboleta; e

- Válvulas de diafragma.

III. Válvulas que permitem o fluxo em um só sentido: instaladas para evitar que o fluxo de gás ocorra no sentido oposto. Não apresentam grande resistência ao escoamento quando ocorre no sentido correto, porém no sentido contrário as válvulas retêm o escoamento, impedindo o retorno do fluxo.

- Válvulas de retenção;

- Válvulas de retenção e fechamento; e

- Válvulas de pé.

IV. Válvulas que controlam a pressão a montante: utilizadas para aliviar a pressão a montante das válvulas caso venha ocorrer alguma anormalidade no sistema. Sua abertura para atmosfera é proporcional aos acréscimos de pressão aplicados acima das condições normais de operação. Elas funcionam da seguinte maneira: quando ocorre um aumento de pressão a montante acima da pressão de segurança de uma determinada tubulação, a válvula abre e libera parte do fluxo de gás para a atmosfera com a finalidade de reduzir a pressão da instalação. São encontradas nos seguintes tipos:

- Válvulas de segurança e alívio;

- Válvulas de excesso de vazão; e

- Válvulas de contrapressão.

V. Válvulas que controlam a pressão a jusantes: destinadas a realizar o controle e regulagem do fluxo conforme a necessidade e pressão da rede a jusante das válvulas. São encontradas nos seguintes tipos:

- Válvulas redutoras e reguladoras de pressão; e

- Válvulas de quebra-vácuo.

A figura 1 mostra uma válvula típica de bloqueio de rede tipo esfera por acionamento manual. 
Figura 1 - Válvula de bloqueio de rede, com acionamento manual

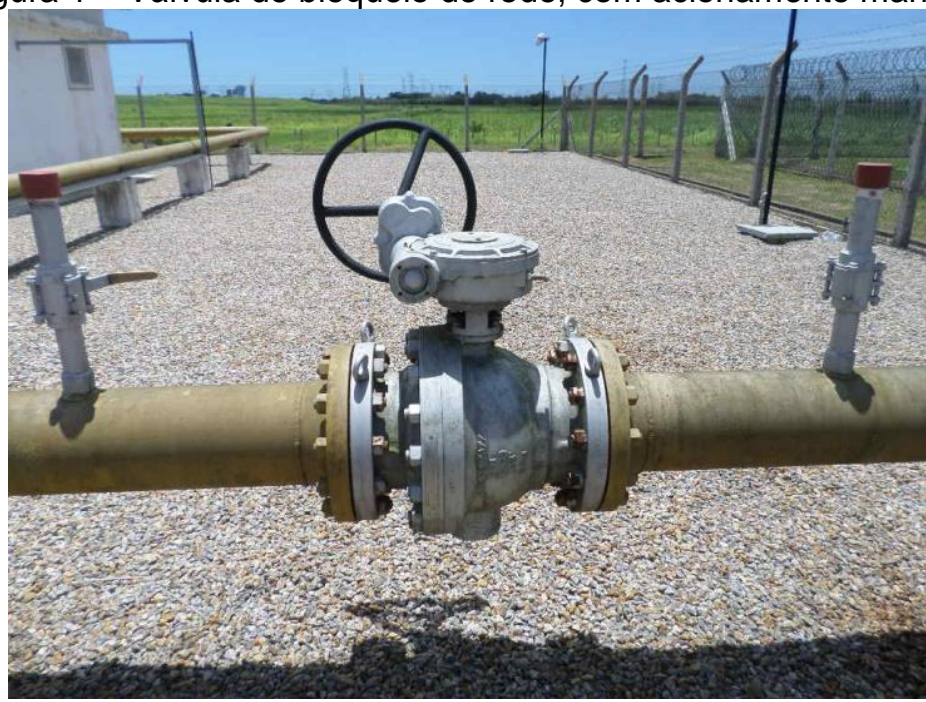

Fonte: Elaborada pelo autor.

\subsection{Filtros}

Os filtros são equipamentos instalados na entrada das estações redutoras de pressão ou nas estações de transferência de custódia. São responsáveis pela eliminação de partículas sólidas suspensas no gás natural provenientes do atrito do gás com as paredes internas dos dutos, resíduos do processo de soldagem dos tubos deixados durante a construção ou de óxidos de ferro provocados por processo de corrosão interna em redes com alto teor de umidade.

O esquema básico dos filtros pode ser visualizado na figura 2.

Figura 2 - Esquema básico de filtragem do gás

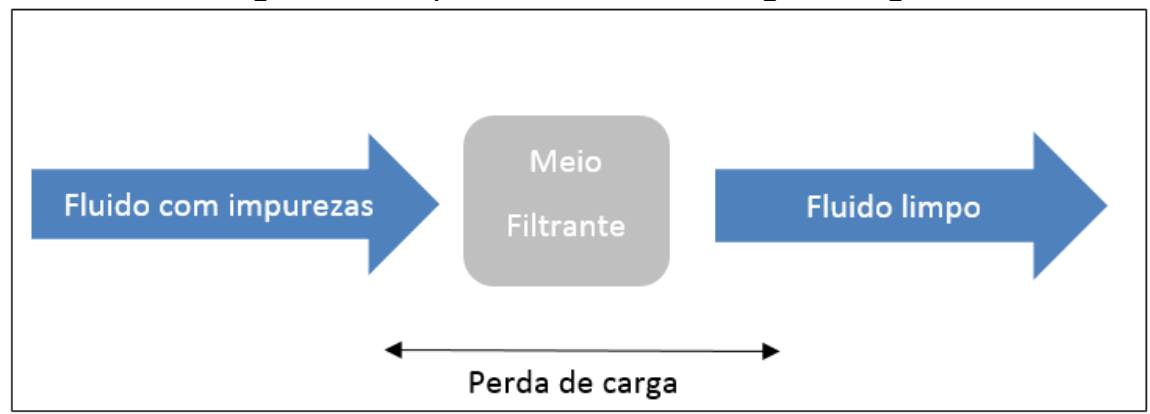

Fonte: Adaptado Monteiro, 2010.

Os filtros podem ser basicamente de dois tipos: filtro tipo cesto ou filtro tipo cartucho. A figura 3 mostra filtros tipo cestos instalados na entrada de uma estação redutora de pressão a sete indica o sentido do fluxo do gás. 
Figura 3 - Exemplo de filtro tipo cartucho

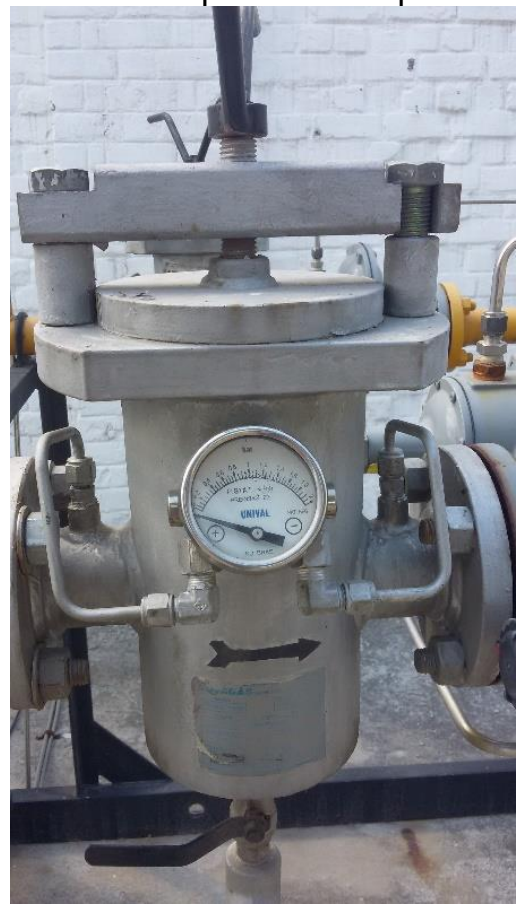

Fonte: Elaborada pelo autor.

\subsection{Regulador de pressão}

Os reguladores de pressão são equipamentos instalados nas estações redutoras de pressão, responsáveis pelo controle da pressão de saída, independentemente de qualquer oscilação da pressão de entrada e vazão. $A$ pressão regulada flutua dentro dos padrões estabelecidos para não comprometer o controle da rede. Os reguladores também são conhecidos como válvulas reguladoras de pressão, são auto operados, ou seja, utilizam a própria energia do gás para estabelecer a pressão desejada. Segundo a norma ABNT NBR 15590 (2008), os reguladores são classificados em três tipos quanto à aplicação:

- Regulador de estágio único: reduz a pressão diretamente para a utilização no equipamento (fornos, caldeiras, aquecedores, etc.);

- $\quad$ Regulador de estágio primário: reduz a pressão da rede para uma pressão de distribuição; e

- Regulador de estágio secundário: reduz a pressão da rede de distribuição do primeiro estágio para uma pressão de utilização dos equipamentos de consumo.

Os reguladores podem ser de dois tipos: reguladores de ação direta ou pilotados. Os pilotados possuem uma melhor estabilidade na pressão regulada de 
saída. Já os de ação direta são mais simples e baratos em comparação aos pilotados. [1]

A figura 04 mostra um diagrama didático de funcionamento do regulador de ação direta. Quando a pressão de saída for maior que a força exercida pela mola, o conjunto do diafragma se moverá para cima, obstruindo a passagem do fluido pelo orifício até que as forças se equilibrem, ou seja, a pressão de saída seja igual a pressão da mola. [1]

Figura 4 - Esquema didático de um regulador de ação direta

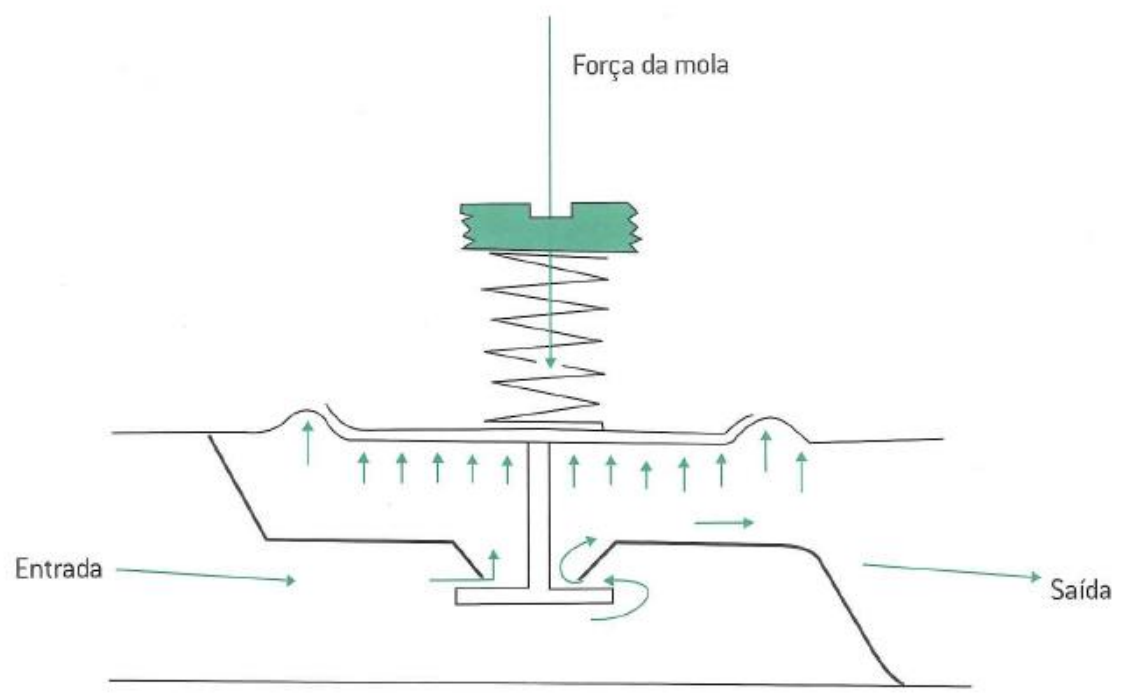

Fonte: Monteiro, 2010.

Figura 5 - Esquema didático de um regulador de ação pilotado

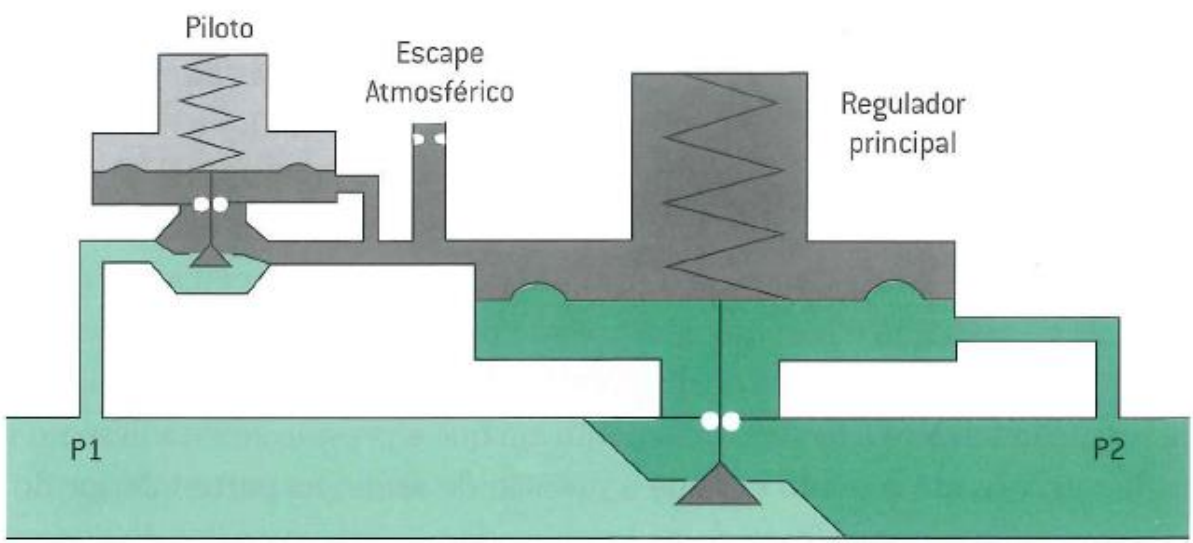

Fonte: Monteiro, 2010. 


\subsection{Estação reguladora de pressão (ERP)}

As estações reguladoras de pressão são compostas por conjuntos de equipamentos interligados que atuam basicamente mantendo a pressão a jusante regulada dentro da MOP. Normalmente elas possuem redundâncias no sistema de regulagem, para que um conjunto atue automaticamente caso outro venha a falhar, de forma a não comprometer o fornecimento de gás. O conjunto é montado normalmente em estrutura metálica, disposta horizontalmente, chamado de cavalete. [1]

Na figura 06, podemos observar uma estação reguladora típica de pressão composta pelos seguintes equipamentos:

- Junta de isolamento elétrico;

- Válvulas de entrada;

- $\quad$ Filtro;

- Válvula de bloqueio automático por sobre pressão;

- $\quad$ Reguladores de pressão;

- $\quad$ Válvula de alívio;

- Válvula de retenção;

- Instrumentação; e

- Válvula de saída.

Figura 06 - Estação reguladora de gás

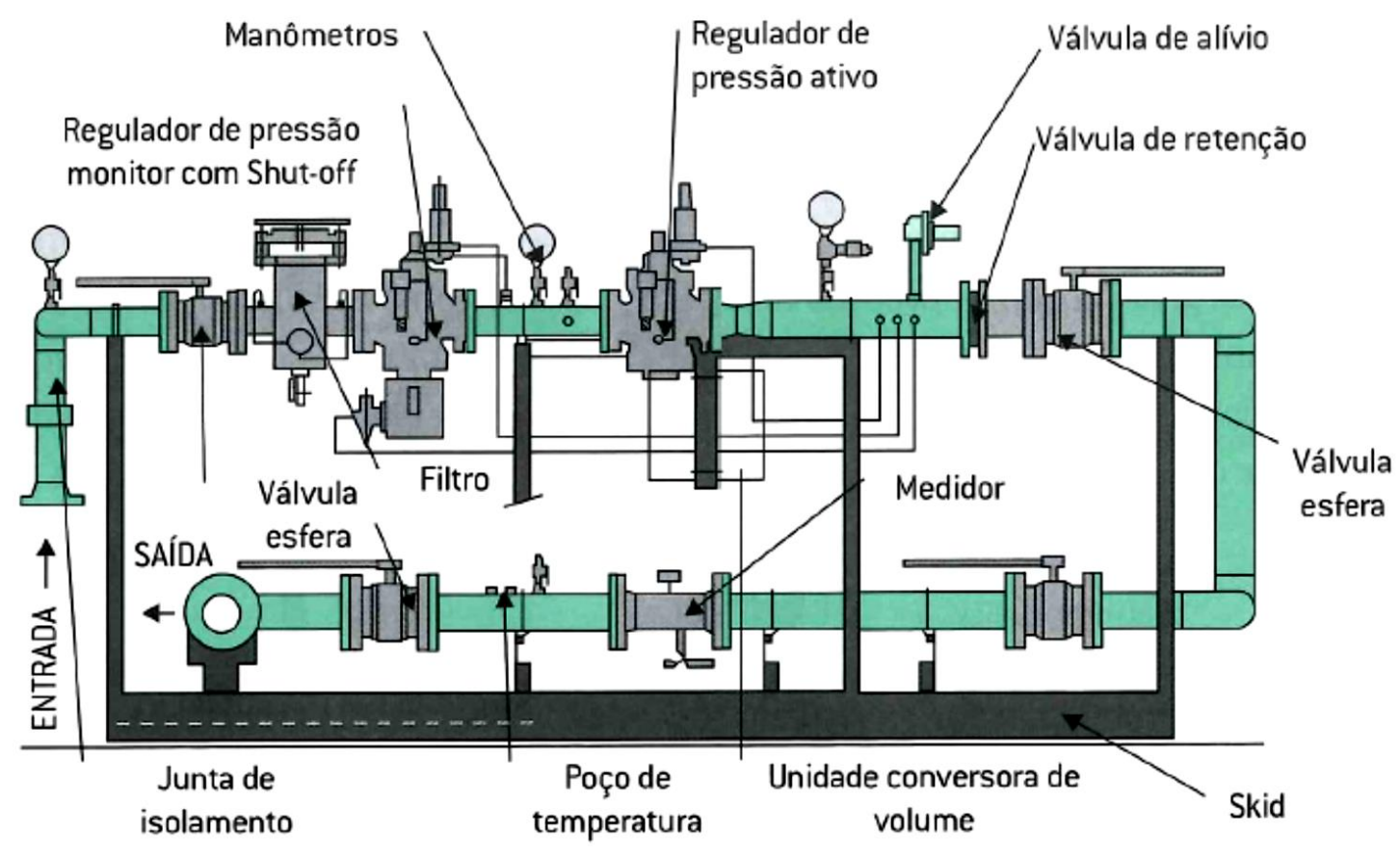

Fonte: Monteiro, 2010. 


\subsection{Sistema de proteção catódica}

A proteção catódica é uma técnica de combate à corrosão empregada em estruturas metálicas. Os gasodutos enterrados que compõem as redes de distribuição de gás natural estão submetidos a processos corrosivos pelo solo. A corrosão dar-se-á pela destruição dos materiais metálicos pela ação química ou eletroquímica do meio, a qual pode estar, ou não, associada a uma ação física. Dentre os fenômenos de corrosão mais importantes, resultantes dessa associação, encontram-se a corrosão pelo solo, corrosão eletroquímica, corrosão por fadiga, corrosão sob tensão. [5]

Existem dois métodos para a aplicação de um sistema de proteção catódica: o método galvânico, ou por anodos de sacrifício, e o método por corrente impressa. Em qualquer um dos dois existe um suprimento de corrente contínua em quantidade tal que, penetrando, por exemplo, em uma tubulação enterrada, é suficiente para eliminar as pilhas de corrosão nela existentes. Na prática, a escolha do método a ser utilizado depende da análise de várias considerações técnicas e econômicas, sendo que cada uma tem vantagens e desvantagens. [6]

Hoje a proteção catódica constitui um novo ramo da engenharia especializada, com seus métodos, equipamentos, materiais e instrumentos, sem os quais não seriam viáveis os milhões de quilômetros de tubulações enterradas e submersas, as grandes instalações portuárias em estrutura metálica e as embarcações de todos os portes, com casco em aço, desde os pequenos barcos até os superpetroleiros. [5] 


\section{MANUTENÇÃO: FUNDAMENTAÇÃO TEÓRICA}

O desenvolvimento do setor produtivo e o avanço da tecnologia tem gerado o aumento da competitividade, e para que as empresas se mantenham competitivas é necessária a adaptação ao cenário atual com a implementação de constantes mudanças. Mesmo gerando conflitos, crises pessoais e organizacionais, mudar pode ser um fator decisivo para o progresso de uma organização e a garantia de sua permanência no mercado, fazendo da manutenção uma função estratégica. [8]

A manutenção, assim como as organizações, tem transitado por constantes mudanças, devido à complexidade e aumento da diversidade de equipamentos, projetos, novas técnicas e novas responsabilidades. A evolução da manutenção pode ser dividida em três gerações: [8]

\section{I.A primeira geração da manutenção}

A primeira geração é referente ao período antes da Segunda Guerra Mundial, com indústrias pouco mecanizadas e equipamentos de baixa complexidade. A prioridade era a produção. A manutenção contínua não era necessária, apenas para reparo após a quebra. Por fundamento, era apenas corretiva. [8]

\section{II.A segunda geração da manutenção}

Esta geração vai da Segunda Guerra Mundial até os anos 60. O período de guerra aumentou a demanda de diversos produtos ao mesmo tempo que o número de trabalhadores diminuiu, o que acarretou um grande aumento da mecanização, assim como a complexidade das instalações. [8]

A busca pela maior disponibilidade de produtos e maior confiabilidade necessitava de uma maior produtividade, que dependia do bom funcionamento das máquinas. Isso levou à ideia de que falhas deveriam ser evitadas e se desenvolveu o conceito de manutenção preventiva. [8]

O custo de manutenção também começou a ser comparado ao custo operacional, o que gerou o desenvolvimento de sistemas de planejamento e controle da manutenção, que hoje fazem parte da manutenção moderna. 
Por fim, foi feita a avaliação do capital investido em itens físicos, levando a avaliação também do custo de capital, ambos focados na busca de meios para aumentar a vida útil dos itens físicos. [8]

\section{III.A terceira geração da manutenção}

A partir da década de 70 , as mudanças nas indústrias aceleraram. A tendência no mundo a utilizar o sistema just-in-time, com estoques reduzidos, justificam pequenas pausas na produção e nas entregas. [8]

Com o desenvolvimento da automação e da mecanização, a disponibilidade e a confiança no processo se tornou essencial em diversos setores. Falhas na automação resultam em dificuldades para manter os padrões de qualidade estabelecidos. [8]

Segundo Pinto (1998, p. 5):

Na Terceira Geração reforçou-se o conceito de uma manutenção preditiva. A interação entre as fases de implantação de um sistema (projeto, fabricação, instalação e manutenção) e a Disponibilidade/Confiabilidade torna-se mais evidente.

A tabela 3 mostra um resumo da evolução da manutenção em relação Ás expectativas de manutenção e aplicação das técnicas.

Tabela 3 - Evolução da manutenção

\begin{tabular}{|c|l|l|l|}
\hline $\begin{array}{c}\text { Primeira Geração } \\
(\mathbf{1 9 3 0 - 1 9 4 0 )}\end{array}$ & \multicolumn{1}{|c|}{$\begin{array}{c}\text { Segunda Geração } \\
(\mathbf{1 9 7 0 )})\end{array}$} & \multicolumn{1}{c|}{$\begin{array}{c}\text { Terceira Geração } \\
\mathbf{( 2 0 0 0 )}\end{array}$} \\
\hline AUMENTO DA EXPECTATIVA EM RELAÇÃO À MANUTENÇÃO & •Maior disponibilidade e \\
\hline •Prioridade era a produção & $\begin{array}{l}\text { •Disponibilidade } \\
\text { Crescente }\end{array}$ & $\begin{array}{l}\text { confiabilidade } \\
\text { •Maior vida útil do } \\
\text { equipamento }\end{array}$ & •Melhor custo-benefício \\
\hline & & •Melhor qualidade dos produtos \\
\hline & & •Preservação do meio ambiente \\
\hline
\end{tabular}




\begin{tabular}{|c|c|c|}
\hline $\begin{array}{l}\text { Primeira Geração } \\
(1930-1940)\end{array}$ & $\begin{array}{l}\text { Segunda Geração } \\
\text { (1970) }\end{array}$ & Terceira Geração (2000) \\
\hline \multicolumn{3}{|c|}{ MUDANÇAS NAS TÉCNICAS DE MANUTENÇÃO } \\
\hline \multirow[t]{2}{*}{ •Conserto após a falha } & $\begin{array}{l}\text {-Computadores grandes e } \\
\text { lentos }\end{array}$ & •Monitoração de condição \\
\hline & $\begin{array}{l}\text {-Sistemas manuais de } \\
\text { planejamento } \\
\text {-Controle do trabalho }\end{array}$ & $\begin{array}{l}\text {-Projetos voltados para a } \\
\text { confiabilidade e manutenibilidade }\end{array}$ \\
\hline & •Monitoração por tempo & •Análise de risco \\
\hline & & -Computadores pequenos e rápidos \\
\hline & & -Softwares potentes \\
\hline & & $\begin{array}{l}\text {-Análise de modos e efeitos da falha } \\
\text { (FMEA) }\end{array}$ \\
\hline & & $\begin{array}{l}\cdot \text { Grupos de } \\
\text { multidisciplinares }\end{array}$ \\
\hline
\end{tabular}

Fonte: Pinto, 1998.

As boas práticas de manutenção consistem em utilizar o que existe de melhor para gerenciar e executar os serviços de manutenção. [8]

As boas práticas visam reduzir o tempo de serviço e evitar o retrabalho, levando a empresa a uma posição de liderança no mercado. Para isso as boas práticas devem estar alinhadas com uma manutenção de classe mundial, o que envolve:

Tabela 4 - Boas práticas de manutenção

\begin{tabular}{|c|c|}
\hline Ação/Condição & Consequências \\
\hline $\begin{array}{l}\text { - Estrutura } \\
\text { - Organização dos times de manizacional } \\
\text { - Integração com área de materiais }\end{array}$ & $\begin{array}{l}\text { - Alta produtividade do pessoal próprio e contratado } \\
\text { - Níveis elevados de segurança } \\
\text { - Melhoria no nível de disponibilidade e confiabilidade } \\
\text { - Ambiente proativo }\end{array}$ \\
\hline 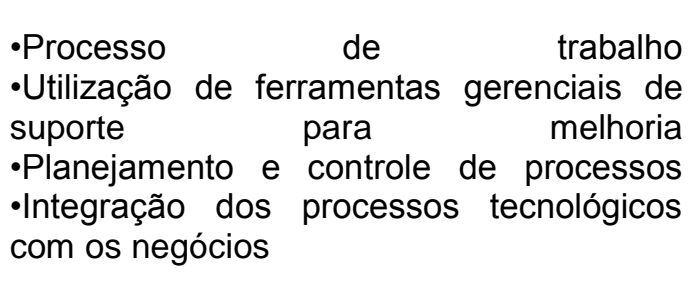 & 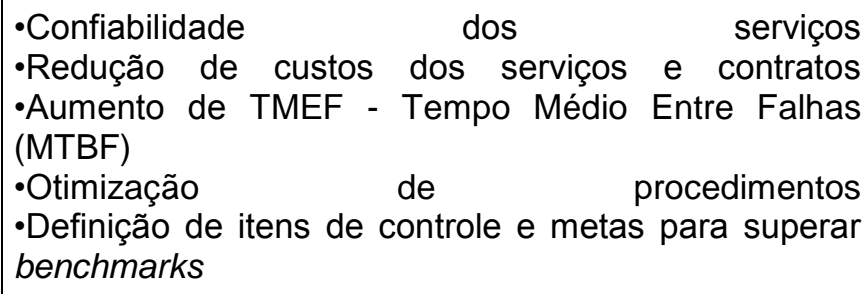 \\
\hline
\end{tabular}




\begin{tabular}{|c|c|}
\hline Ação/Condição & Consequências \\
\hline 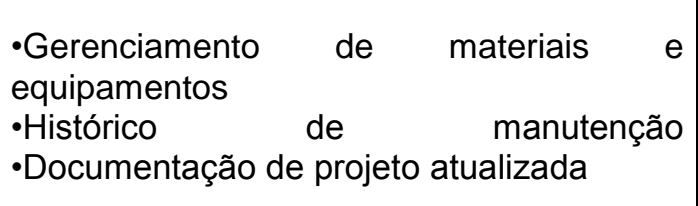 & $\begin{array}{l}\text { - Materiais e sobressalentes } \\
\text { - Redução de inventário de estoques - padronização, } \\
\text { política de recuperação compartilhada com } \\
\text { fornecedores } \\
\text { - Base de dados consolidada para consulta e controle }\end{array}$ \\
\hline
\end{tabular}

\section{TIPOS DE MANUTENÇÃO EMPREGADOS}

\subsection{Manutenção corretiva}

A manutenção corretiva é a atuação para a correção da falha ou do desempenho menor do que o esperado. Nem sempre a manutenção corretiva é uma emergência. [8]

Conforme Filho, Gil Branco (2006, p. 76):

A manutenção corretiva é: (1) - Toda manutenção efetuada em uma máquina, equipamento, sistema operacional, unidade ou item como resultado de falha, para devolver ao item a condição para que ele possa desempenhar sua função. Isto pode incluir as seguintes tarefas: localizar a pane, isolar a pane, desmontar as partes, trocar ou substituir peças ou componentes, remontar o conjunto, alinhar ou ajustar, fazer teste funcional e algumas revalidações.

Com base nos textos acima, podemos observar duas características para que a manutenção seja classificada como manutenção corretiva:

a) Quando variáveis operacionais identificam que o desempenho não está dentro do esperado;

b) Quando é identificada a falha.

Com isso a manutenção corretiva tem como objetivo corrigir ou restaurar o funcionamento de um sistema ou um equipamento. Ela pode ser classificada em duas classes:

- Manutenção corretiva não planejada, que tem uma falha aleatória; e

- Manutenção corretiva planejada, também chamada de preditiva.

A manutenção corretiva atua sobre um fato já ocorrido e normalmente não há tempo para programação do serviço. Mesmo não sendo o ideal, é o mais praticado. A manutenção corretiva, quando não é planejada, normalmente acarreta altos custos, pois há demora no reparo das falhas, podendo gerar perdas significativas na produção e na qualidade, aumentando também os custos indiretos de manutenção. [8] 
As quebras aleatórias podem também trazer a extensão de danos a outros equipamentos, com consequências graves para o processo produtivo. Interromper processos produtivos de maneira inesperada pode comprometer a qualidade dos equipamentos que estavam operando adequadamente. E, quando a maior parte da manutenção é corretiva, o departamento de manutenção é comandado pelos equipamentos, modelo não viável no cenário atual. [8]

\subsection{Manutenção preventiva}

A manutenção preventiva prevê ações que visam reduzir ou evitar a falha ou redução no desempenho, direcionando a um plano elaborado, baseado em intervalos definidos de tempo. A manutenção preventiva tem como principal característica desenvolver ações a fim de evitar que a falha aconteça, ou seja, o objetivo é prevenir. [8]

Conforme Filho e Gil Branco (2006, p. 78):

A manutenção preventiva é: (1) - Todo o trabalho de manutenção realizado em máquinas que não estejam em falha, ou executada antes da ocorrência da falha, estando com isso em condições operacionais, ou no máximo em estado de defeito.

A manutenção preventiva tem vários desafios, pois nem sempre os fabricantes dão detalhes dos equipamentos necessários para realizar um estudo de periodicidade de manutenção, ou até mesmo para acompanhamento da definição da periodicidade de manutenção indicada pelo fabricante, necessária para cada ambiente em que está localizado o equipamento. [8]

Isso leva à ocorrência de alguns fatos:

a) Ocorrência de falhas antes do tempo previsto, para intervenção; e

b) Reposição prematura de componentes.

Porém ao longo da vida útil do equipamento podem ocorrer falhas entre o período das intervenções preventivas, gerando uma ação corretiva. Alguns fatores que devem ser considerados para a inserção de política de manutenção preventiva são:

- Quando não ocorre a manutenção preditiva;

- Segurança do pessoal, ou de instalações que tornam necessárias uma intervenção, para substituir componentes;

- Manutenção em equipamentos críticos, que sua manutenção gera impactos significativos na produção; 
- Impactos agressivos no meio ambiente; e

- Em sistemas em operação continua e complexos.

\subsection{Manutenção preditiva}

A manutenção preditiva, também conhecida como manutenção corretiva programada, atua sobre a condição do equipamento ou sobre o estado do equipamento, segundo Pinto (1999, p. 37). "Manutenção preditiva é a atuação com base em modificações de parâmetros de condição ou desempenho, cujo acompanhamento obedece a uma sistemática".

Conforme Filho e Gil Branco (2006, p. 78), "A manutenção preditiva é: (1) - Todo o trabalho de acompanhamento de monitoramento das condições das máquinas e de seus parâmetros operacionais e sua degradação".

A manutenção preditiva atua em prevenir possíveis falhas ou quebras dos equipamentos e sistemas baseando-se na análise dos parâmetros de funcionamento dos equipamentos com base em sua eficiência de produção, o que permite a operação contínua do equipamento ou sistema pelo maior tempo possível. [8]

$\mathrm{Na}$ realidade do termo, manutenção preditiva é predizer as futuras quebras dos equipamentos com base nos dados de históricos de desempenho. Privilegia a disponibilidade à medida que não promove a intervenção nos equipamentos e sistemas de forma equivocada. [8]

Quando os indicadores que medem a eficiência do sistema ou equipamento estão próximos do limiar inferior de operação pré-estabelecido, é tomada a descrição de intervenção. Normalmente esse acompanhamento é realizado com o auxílio de gráficos que mostram o desempenho do equipamento por intervalo de tempo. De certa forma, a manutenção preditiva se antecipa a futuras quebras ou paradas inesperadas; o que se faz, na realidade, é uma intervenção corretiva planejada. [8]

Segundo Pinto (1999, p. 38), as condições básicas para se adotar a manutenção preditiva são as seguintes:

- $O$ equipamento, o sistema ou a instalação devem permitir algum tipo de monitoramento ou medição;

- O equipamento, o sistema ou a instalação devem merecer esse tipo de ação, em função dos custos envolvidos; 
- As falhas devem ser oriundas de causas que possam ser monitoradas e ter sua progressão acompanhada; e

- Deve ser estabelecido um programa de acompanhamento, análise e diagnósticos sistematizado.

Um dos mais significantes benefícios que as atividades de manutenção preditiva traz para as máquinas, equipamentos e instalações é a redução de acidentes por falhas "catástrofes". Além disso, proporciona um aumento na segurança do pessoal de operação, da instalação e da redução de paradas inesperadas de produção da planta, as quais, dependendo do tipo da planta, pode acarretar grandes prejuízos materiais, ambientais e humanos. [8] 


\section{SISTEMA DA INFORMAÇÃO}

A informação é uma seleção de dados organizados que fazem referência a um acontecimento ou a um fato, É o produto gerado pelo processamento e manipulação de dados e gera conhecimento para a pessoa que a utiliza. Deve ser compreendida e possuir valor nas decisões presentes e futuras.

Informação e dados são comumente usados como sinônimos, mas eles são muito diferentes. Informação é um conjunto de dados organizados de forma lógica, capaz de transmitir uma ideia ou um pensamento.

Por mais que um indivíduo tenha grande quantidade de dados, por não terem uma relação significativa, vinculados ou organizados de maneira lógica, não gera conhecimento. Já a informação possibilita o seu entendimento e agrega algum valor àquele que a utiliza. Atualmente a informação é um dos recursos mais valiosos de uma empresa, contribuindo muito para manter a sua competitividade.

\subsection{Características e valor da Informação}

Uma informação deve ser completa, caso contrário o usuário que utilizar pode tomar decisões equivocadas, podendo gerar grandes prejuízos sociais e econômicos para a empresa. A informação pode apresentar características diferentes de acordo com a importância que lhe é atribuída.

Conforme Padoveze (2000, p. 43), para que a informação seja considerada valiosa, ele deve atender aos seguintes requisitos:

Tabela 5 - Características da informação

\begin{tabular}{|c|c|c|c|c|}
\hline \multicolumn{5}{|c|}{ Características da Informação } \\
\hline conteúdo & precisão & atualidade & freqüência & relevância \\
\hline entendimento & confiabilidade & relatividade & exceção & acionabilidade \\
\hline flexibilidade & motivação & \multirow{2}{*}{ segmentação } & consistência & integração \\
\hline oportunidade & objetividade & & volume & generalidade \\
\hline \multicolumn{2}{|c|}{ uniformidade de critério } & \multirow{2}{*}{ seletividade } & \multicolumn{2}{|c|}{ valor econômico } \\
\hline \multicolumn{2}{|c|}{ indicação de causas } & & \multicolumn{2}{|c|}{ adequação a decisão } \\
\hline
\end{tabular}

Fonte: Padoveze, 2000.

Já para Strassburg (2004, p. 56), as características da informação são as seguintes: 
Tabela 6 - Características da informação II

\begin{tabular}{|c|c|c|c|}
\hline \multicolumn{4}{|c|}{ Características da Informação } \\
\hline útil & reutilizável & deve informar & é um ativo \\
\hline deve ser gerenciada & deve ser oportuna & permite análises & São dados em uso \\
\hline tem valor econômico & não se deteriora & deve ter limites & Está no relatório final \\
\hline $\begin{array}{c}\text { o seu valor é } \\
\text { determinado pelo usuário }\end{array}$ & $\begin{array}{l}\text { deve servir de base } \\
\text { para os gestores }\end{array}$ & $\begin{array}{l}\text { deve ser discutida no } \\
\text { contexto do usuário }\end{array}$ & $\begin{array}{l}\text { não se deprecia em } \\
\text { função do uso }\end{array}$ \\
\hline $\begin{array}{c}\text { é composta de: dados } \\
\text { coletados organizados e } \\
\text { ordenados }\end{array}$ & $\begin{array}{c}\text { deve atender as } \\
\text { necessidades dos } \\
\text { usuários }\end{array}$ & $\begin{array}{c}\text { deve dar condições de } \\
\text { comparação e } \\
\text { relacionamento }\end{array}$ & $\begin{array}{c}\text { serve de apoio às } \\
\text { estratégias e tomada } \\
\text { de decisão }\end{array}$ \\
\hline
\end{tabular}

Fonte: Padoveze, 2000.

A informação que possui essas características pode ser considerada muito valiosa, pois estará próxima daquilo que os gestores necessitam para a tomada de decisão e consequentemente manter o bom andamento da organização, assim como atingir metas e oferecer aos seus clientes melhores propostas.

Se as informações não tiverem as características descritas na tabela 5 e 6 , elas podem comprometer a continuidade da empresa, pois os gestores poderão tomar decisões equivocadas. Se uma informação indica à empresa uma necessidade de investimento desnecessário, o mesmo se torna um prejuízo, e isso poderá ocorrer devido a uma informação não ter precisão.

O valor de uma informação está diretamente ligado à sua importância para os tomadores de decisão atingirem suas metas e objetivos — redução da incerteza e relação custo benefício -, gerando o aumento da qualidade da decisão a um custo viável para a empresa.

\subsection{Tecnologia da Informação}

Por muitos anos, poucas pessoas trabalhavam no departamento de CPD (Centro de Processamento de Dados) e a tecnologia da informação foi tratada como uma parte que não pertencia à empresa. Atualmente os processos industriais utilizam a tecnologia da informação através de maquinários que melhoram a qualidade e quantidade de seus produtos. Contínuas mudanças nos últimos anos, provocadas pelo aumento do número de empresas, estimularam a competitividade, fazendo com que as empresas façam investimentos que tragam aperfeiçoamento e garantam sua permanência no mercado.

Um exemplo atual da utilização da tecnologia da informação: de acordo com o Jornal Valor Econômico de 03/10/2014, "o Rio Grande do Sul é o estado com o maior número de municípios com votação biométrica no pleito de outubro, segundo o Tribunal Regional Eleitoral (TRE-RS). Ao todo, 752.026 eleitores, em 186 cidades, serão identificados, no domingo (5), por meio da impressão digital." 
A tecnologia da informação, nesse caso, foi utilizada para agilizar e garantir a confiabilidade da votação, visivelmente trazendo melhorias ao processo de apuração e confiabilidade para as pessoas envolvidas.

Para Cruz (2000, p. 24), "tecnologia da informação é todo e qualquer dispositivo que tenha capacidade para tratar dado e ou informações, tanto de forma sistêmica como esporádica, quer esteja aplicada no produto, quer esteja aplicada no processo".

Segundo Alecrim (2013):

Sendo a informação um patrimônio, um bem que agrega valor e dá sentido às atividades que a utilizam, é necessário fazer uso de recursos de TI de maneira apropriada, ou seja, é preciso utilizar ferramentas, sistemas ou outros meios que façam das informações um diferencial. Além disso, é importante buscar soluções que tragam resultados realmente relevantes, isto é, que permitam transformar as informações em algo com valor maior, sem deixar de considerar o aspecto do menor custo possível.

Com o aumento da concorrência a informação tornou-se importante em todos os processos, pois através dela se conhece os custos de produção, custo de manutenção, preço de venda, margem de lucro e outros fatores indispensáveis para o bom desempenho da empresa.

Para Drucker (2001, p. 87), o mundo se encontra na quarta Revolução da Informação, tendo passado pelos seguintes acontecimentos:

Tabela 7 - As revoluções da informação

\begin{tabular}{|c|c|l|c|}
\hline $\begin{array}{c}\text { Revolução da } \\
\text { Informação }\end{array}$ & Época & \multicolumn{1}{|c|}{ Acontecimento } & \multirow{2}{*}{$\begin{array}{c}\text { Revolução } \\
\text { da } \\
\text { Imprensa }\end{array}$} \\
\hline $1^{\text {a }}$ & $+/-4.000$ a.C & Invenção da escrita & \\
\hline $2^{\text {a }}$ & 1.300 a.C & Criação de livros escritos a mão & \\
\hline $3^{\text {a }}$ & 1.450 & Invenção da impressora com tipos móveis & \\
\hline $4^{\text {a }}$ & 1.950 & Informações com foco na decisão & \\
\hline
\end{tabular}

Fonte: Drucker, 2001.

A tecnologia da informação tem um papel muito importante na restrição, precisão e agilidade em gerar informações, sendo isso um diferencial competitivo nas empresas. 


\subsection{Sistemas da Informação}

Os sistemas de informação possibilitam acesso a informações de maneira rápida, facilitando o processo de decisão para os gestores. Para Padoveze (2010, p. 48), o Sistema de Informações, pode ser conceituado como:

Um conjunto de recursos humanos, materiais, tecnológicos e financeiros agregados segundo uma sequência lógica para o processamento dos dados e tradução em informações, para com seu produto, permitir às organizações o cumprimento de seus objetivos principais.

Desta maneira o sistema de informação é o somatório de diversos elementos inter-relacionados que coletam, processam, armazenam e difundem os dados, transformando-os em informações úteis aos gestores.

Para Strassburg (2004, p. 61):

Os conceitos de sistema de informação estão fundamentados em três elementos básicos e fundamentais para a obtenção do resultado esperado, que são: entrada de dados, o processamento destes dados e a saída dos dados transformados (informação).

A entrada de dados (input) é a captação dos dados que serão utilizados para gerar a informação. Esses dados podem ter fontes internas ou externas a empresas, sempre levando em consideração o resultado esperado.

O processamento dos dados (processing) é onde os dados são transformados em informação que sejam utilizadas conforme a necessidade do solicitante. O processamento pode envolver cálculos, comparações e armazenagem de dados.

Na saída, para que a informação seja utilizada pelos gestores, geralmente são utilizados relatórios e dados extraídos de transações específicas do sistema de informação. Vale ressaltar que a saída de um sistema pode se tornar entrada de outro, ou até mesmo o controle de outros. Outro fator importante é a retroalimentação (feedback), conforme figura 7 , pois diz respeito aos erros e acertos na entrada e no processamento dos dados, sendo um elemento básico para a obtenção do resultado citado acima. Com o feedback, erros nos dados ou no processamento podem ser corrigidos, e por esse motivo ele se torna muito importante para os tomadores de decisão. 
Figura 7 - Fluxo da Informação

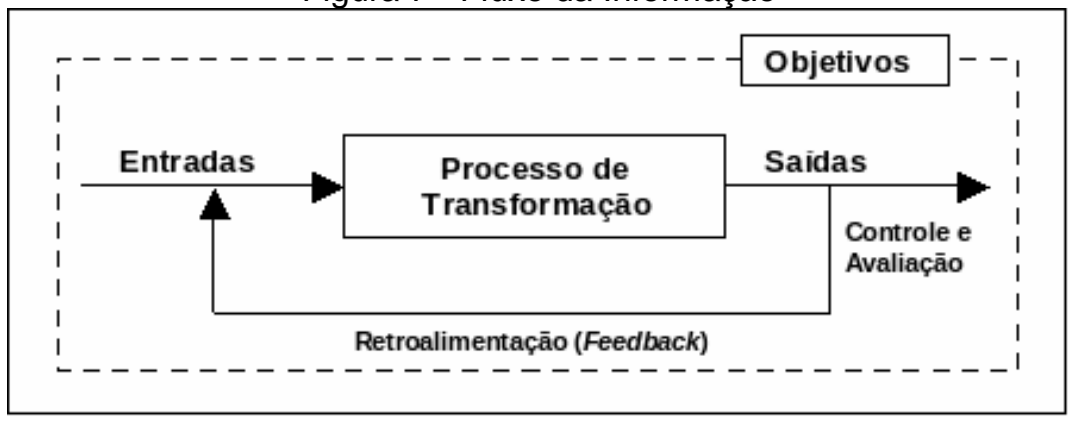

Fonte: Elaborada pelo autor.

Os sistemas de informação podem ser abertos ou fechados (PADOVEZE, 2010). O sistema aberto interage com o ambiente externo. Todas as empresas são sistemas abertos. Por exemplo: matérias-primas entram no sistema e após o processamento de bens e serviços saem para o ambiente, para clientes e compradores. Já no sistema fechado não há nenhuma interação com o ambiente externo.

O sistema de informação é responsável por processar um grande volume de dados e gerar informações periódicas de planejamento e controle, trazendo alternativas para apoiar os gestores na tomada de decisão. Seus principais elementos são: objetivos, ambiente, recursos, componentes, saídas controle e avaliação do sistema.

Podemos classificar os sistemas de informação como de apoio às operações e de apoio à gestão. Na gestão, o sistema apoia os gestores com informações que refletem a situação real da empresa com todas as transações realizadas, melhorando o desempenho da empresa e a tomada de decisão; na operação, auxilia os departamentos a exercerem com controle as suas funções operacionais como produção, compra e venda.

\subsection{Sistemas da informação integrados de gestão}

Os sistemas de informação têm como principal objetivo consolidar, interligar todos os dados em seu sistema necessários à sua gestão e gerar informações vinculadas a vários setores, desenhadas para atendimento gerencial.

Segundo Padoveze (2010, p. 49):

Esses sistemas unem e integram todos os subsistemas componentes dos sistemas operacionais e dos sistemas de apoio à gestão, através de recursos da tecnologia de informação, de forma tal que todos os processos de negócios da empresa possam ser visualizados em termos de um fluxo dinâmico de informações, que perpassam todos os departamentos e funções. Permitem, com isso, uma visão 
horizontal e de processo, em oposição à visão tradicional verticalizada da hierarquia funcional das empresas. O Sistema de Informação Contábil deverá estar completamente integrado ao Sistema de Gestão Empresarial.

Os Sistemas Integrados de Gestão são chamados de Enterprise Resource Planning-ERP. Esses sistemas permitem serem interligados a outras tecnologias de informação como Cadeia de Suprimentos, Workflow etc., assim como integração com rede e internet. 


\section{ESTUDO DE CASO}

\subsection{Descrição da empresa}

A Empresa GBM é uma das maiores distribuidoras de gás natural do país e faz parte de um grupo internacional de energia. Atualmente está presente em três unidades federativas do Brasil, com presença em 50 municípios, onde conta com mais de 1,5 milhão de clientes distribuídos nos ramos industrial, geração de energia e residencial, com consumo médio diário de 14 milhões de metros cúbicos de gás natural. Possui uma malha de distribuição (com pressão máxima de operação de 42 bar) de $8.000 \mathrm{~km}$ de rede. Na figura 8 , observa-se a evolução do crescimento em média de 100 mil por ano.

Figura 8 - Evolução de clientes nos últimos cinco anos

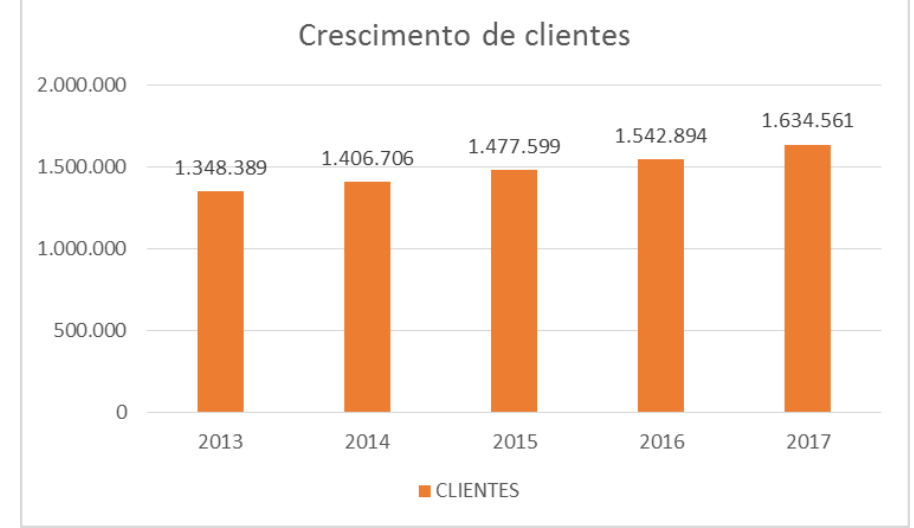

Fonte: Elaborada pelo autor.

\subsection{A manutenção na empresa GBM}

A GBM é uma empresa compromissada com os requisitos de manutenção de seus ativos. Atualmente possui um setor responsável por todo o planejamento de manutenção preventiva da companhia. Anualmente são publicados planos de manutenção que são utilizados pelos diversos setores da empresa.

A figura 9 ilustra a evolução do gasto com a manutenção de 2014 até 2018. Observa-se uma evolução entre $2 \%$ e $4 \%$ ao ano. Vale a pena ressaltar que 0 custo de manutenção para 2018 está projetado com base no orçamento vigente. 
Figura 9 - Custo com Manutenção

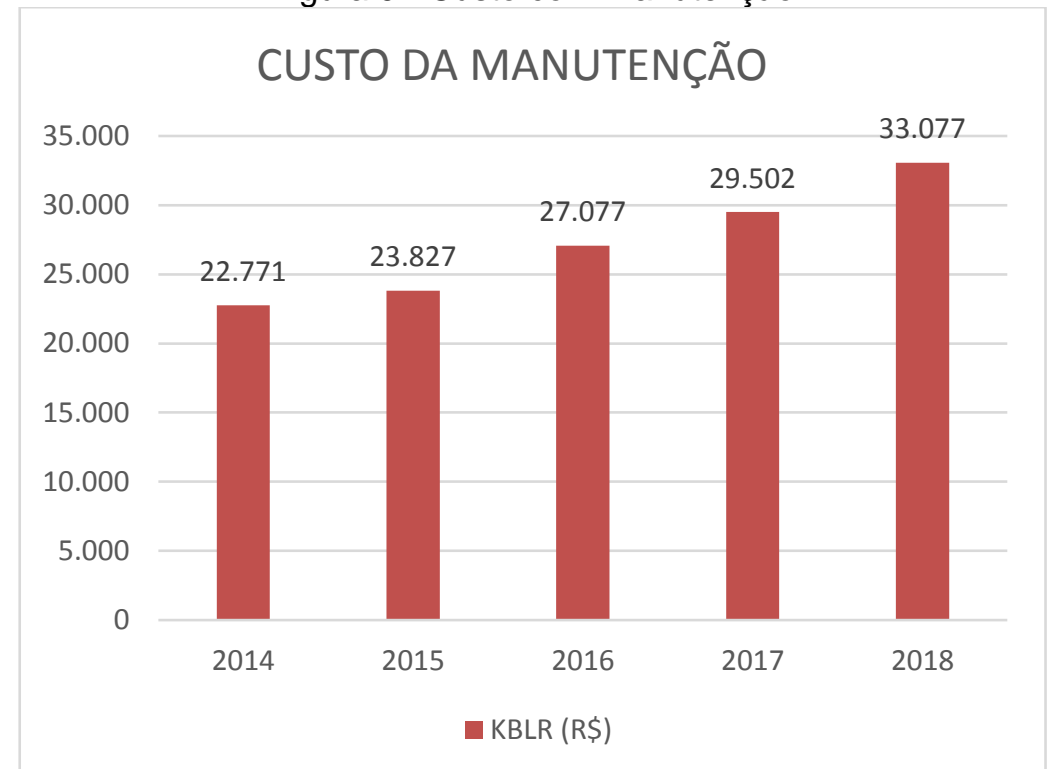

Fonte: Elaborada pelo autor.

\subsection{Estrutura organizacional da manutenção}

Figura 10 - Estrutura organizacional da manutenção

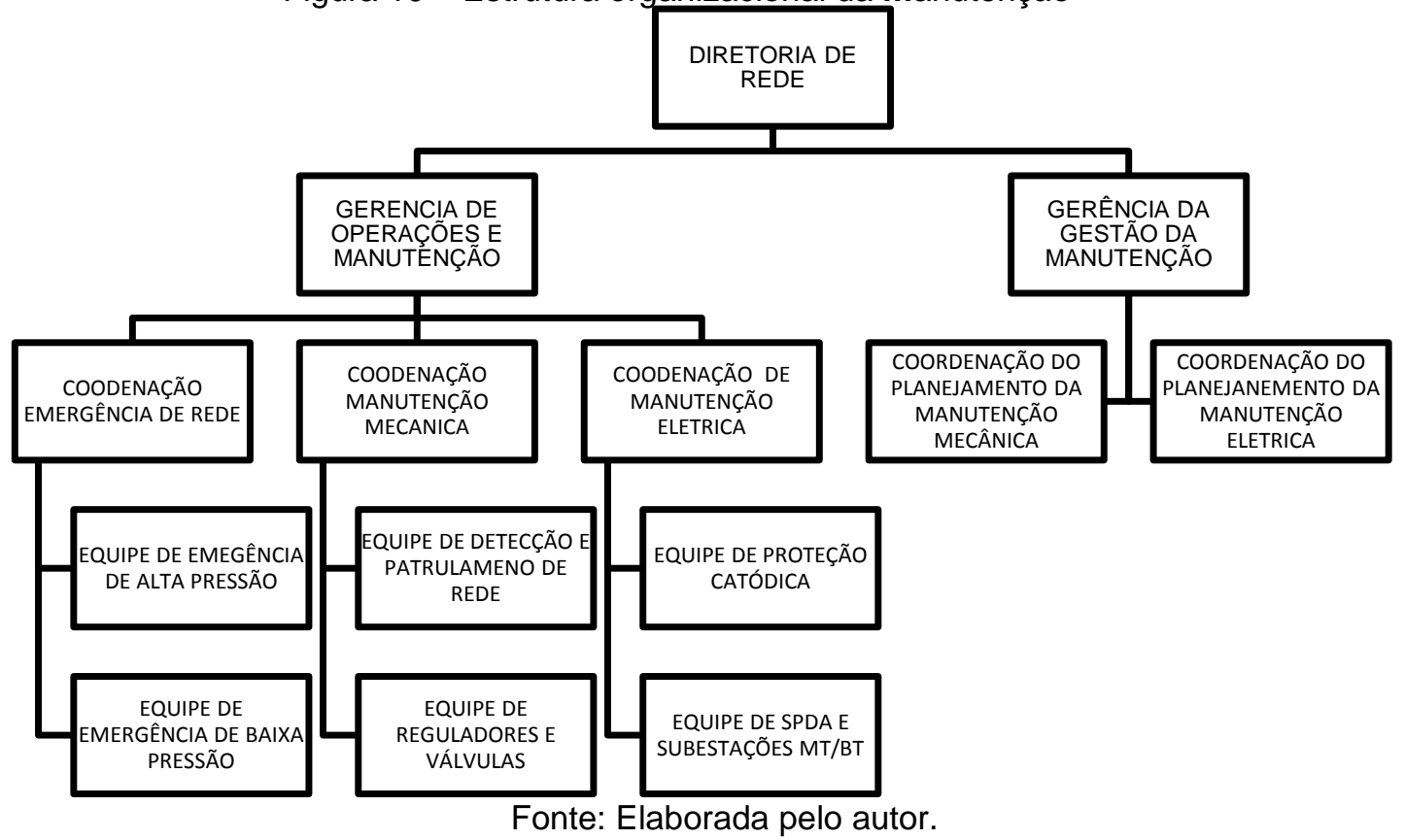

\subsection{Fluxo do processo da manutenção na GBM}

Todo o processo da manutenção é realizado no sistema SAP PM sem a necessidade de formulários físicos. A coordenação do setor de planejamento da manutenção é responsável pela geração das OT. No dia 12 de cada mês são geradas automaticamente e enviadas por e-mail à empresas colaboradoras todas 
as ordens preventivas a serem realizadas durante o mês seguinte. Por exemplo, no dia 12 de outubro serão criadas todas as ordens que devem ser realizadas desde o dia $1^{\circ}$ até o dia 31 de novembro. Cada ordem é atribuida a uma empresa colaboradora. Após a execução das ordens de trabalho o detalhamento das atividades de manutenção são inseridas no sistema.

Quando as OT são enceradas no SAP PM pela empresa colaboradora, os responsáveis pelo setor de operação da manutenção devem fazer uma checagem dos trabalhos realizados pelas empresas colaboradoras e certificá-los através de boletim de medição assinados pela área onde foi realizado o serviço.

A figura 11 ilustra o diagrama de fluxo básico da manutenção.

Figura 11 - Diagrama de fluxo básico da manutenção

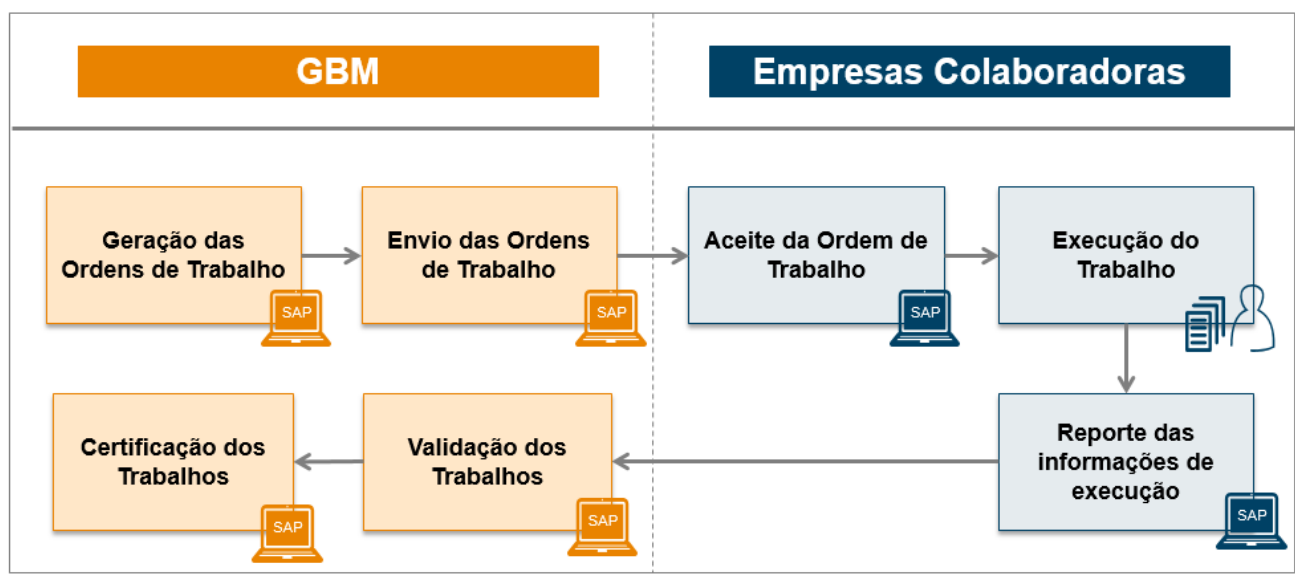

Fonte: Elaborada pelo autor.

\subsection{Gerenciamento da manutenção ERP SAP R3 - Módulo PM}

Uma das funções do módulo PM é a gestão do inventário dos ativos, ou seja, cadastramento de novos equipamentos, inclusão de dados técnicos operacionais e controle de garantia do fabricante. Uma vez que os ativos são inventariados, os dados são inseridos no sistema, sendo possível programar o módulo PM para emissão de ordens de trabalho "OT" de manutenção de origem preventiva, corretiva e preditiva para esses equipamentos, além da possibilidade de criação de notas técnicas de manutenção referentes a avarias e anomalias identidades por terceiros.

O módulo PM, assim como os demais módulos da plataforma SAP, utiliza a unidade básica chamada de transação (código alfanumérico) para a criação, edição e consulta de dados técnicos. As transações do módulo PM são ferramentas sistêmicas que servem para criar, editar, exibir equipamentos e 
estruturas, programar planos de manutenção e gerar relatórios gerenciais de manutenção. As transações são compostas por uma sucessão de telas formadas por diferentes campos.

A tabela 8 mostra um resumo das transações básicas que mais são utilizadas normalmente.

Tabela 8 - Transações básica do SAP PM

\begin{tabular}{|c|l|c|l|}
\hline Transação & \multicolumn{1}{|c|}{ Aplicação } & Transação & \multicolumn{1}{c|}{ Aplicação } \\
\hline IE01 & Criação de equipamentos & IK03 & Visualiza pontos de medição \\
\hline IE02 & Edição de equipamentos & IL01 & Cria locais de equipamentos \\
\hline IE03 & Visualização de Equipamentos & IL02 & $\begin{array}{l}\text { Edita locais de } \\
\text { equipamentos }\end{array}$ \\
\hline IW21 & $\begin{array}{l}\text { Criação de notas de } \\
\text { manutenção }\end{array}$ & IL03 & $\begin{array}{l}\text { Visualiza locais de } \\
\text { equipamentos }\end{array}$ \\
\hline IW22 & $\begin{array}{l}\text { Edição de notas de } \\
\text { manutenção }\end{array}$ & CL01 & Cria classes de manutenção \\
\hline IW23 & $\begin{array}{l}\text { Visualização de notas de } \\
\text { manutenção }\end{array}$ & CL02 & $\begin{array}{l}\text { Edita classes de } \\
\text { manutenção }\end{array}$ \\
\hline IP01 & $\begin{array}{l}\text { Cria Planos de manutenção } \\
\text { IP02 }\end{array}$ & CL03 & $\begin{array}{l}\text { Visualiza classes de } \\
\text { manutenção }\end{array}$ \\
\hline IP03 & $\begin{array}{l}\text { Visualiza Planos de } \\
\text { manutenção }\end{array}$ & IP10 & $\begin{array}{l}\text { Realiza a programação de } \\
\text { planos de manutenção }\end{array}$ \\
\hline IH08 & $\begin{array}{l}\text { Gera relatório de listas de } \\
\text { inventários dos equipamentos }\end{array}$ & $\begin{array}{l}\text { Cria estratégias de } \\
\text { manutenção }\end{array}$ \\
\hline IIW39 & $\begin{array}{l}\text { Gera relatórios de situação de } \\
\text { OT emitidas }\end{array}$ & IK02 & Cria pontos de verificação \\
\hline & Edita pontos de verificação \\
\hline
\end{tabular}

Fonte: Elaborada pelo autor.

A figura 12 ilustra o Menu de trabalho. A navegação dentro do Menu realizase através de um conjunto de pastas que organizam e estruturam os módulos do SAP com suas transações em forma de árvore.

Figura 12 - Sistema SAP PM

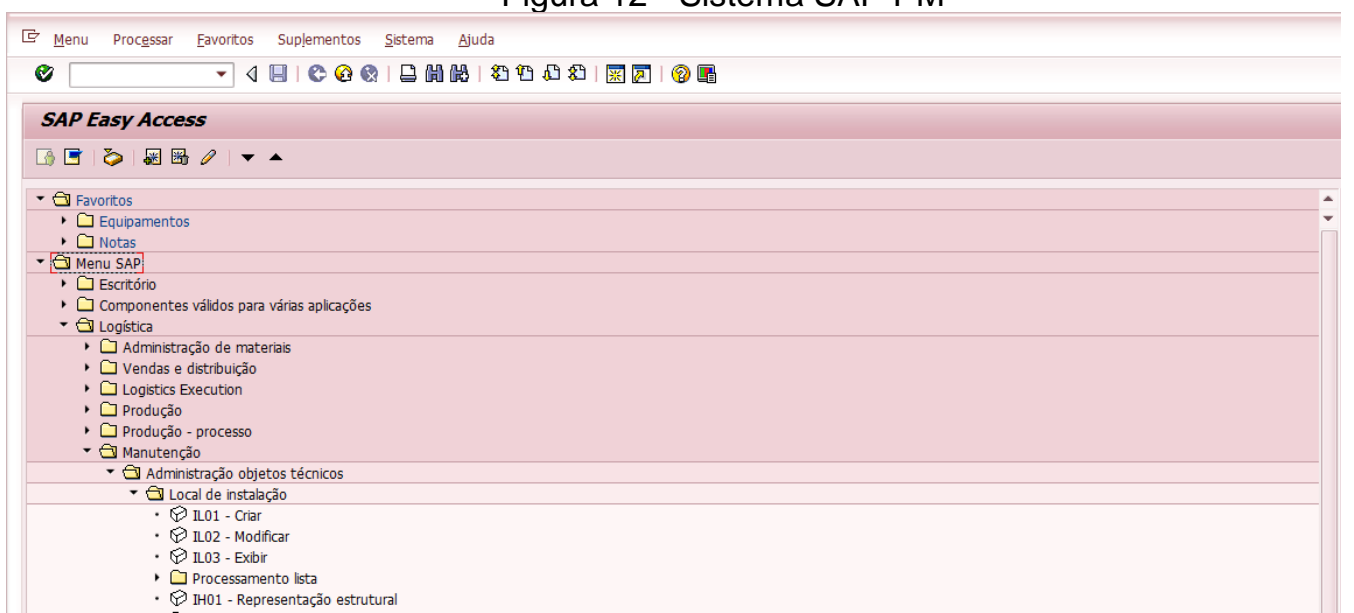

Fonte: Print screen da aplicação do sistema SAP PM. 


\subsection{Descrição da estrutura hierárquica do SAP PM}

A estrutura do sistema do módulo SAP PM foi baseada no seguinte modelo hierárquico, conforme figura 13.

Figura 13 - Descrição da estrutura hierárquica do SAP PM

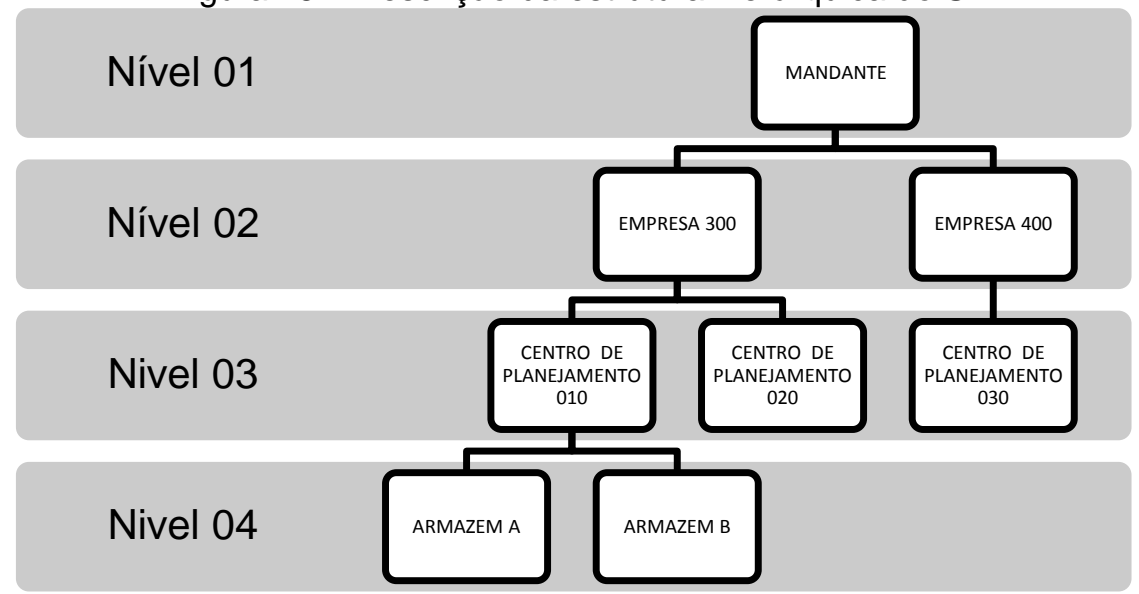

Fonte: Print screen da aplicação do sistema SAP PM.

O mandante é a unidade básica da estrutura lógica no módulo PM, que contém suas próprias regras de negócio, estrutura organizacional e dados de aplicação. Uma entrada de mandante é utilizada em todos os registros mestre, o que garante que eles são gravados por mandante.

O segundo nível da hierarquia define as empresas que estão ligadas ao mandante. Um mandante pode ter várias empresas alocadas.

O terceiro nível define os centros de planejamento, que são unidades físicas ou fictícias de manutenção responsáveis por todo o planejamento de uma determinada área ou setor.

O quarto nível engloba os armazéns físicos ou fictícios, que correspondem ao lugar onde estão alocados os equipamentos, matérias, ferramentais etc.

\subsubsection{Equipamentos}

Os equipamentos são elementos primários na estrutura do SAP PM, somente eles podem ser passíveis de manutenção. Estão divididos por categoria. Todos os equipamentos estão alocados em uma localização técnica associada à estrutura geopolítica do país e definida do nível do mais alto para o nível mais baixo. 
A localização técnica é identificada por uma codificação formada por quatro campos distintos: o primeiro campo, com cinco caracteres da direita para esquerda, faz referência à empresa; o segundo campo, com dois algarismos, determina o estado (UF); o terceiro campo, com 5 algarismos, é o município; o quarto campo, com 6 algarismo, define o nível mais baixo, o bairro. Os códigos do estado, município e bairro são definidos conforme sistema de codificação do IBGE.

O cadastramento do equipamento pode ser realizado de duas formas: manualmente pela transação IE01 ou por meio de cargas massivas através de planilhas eletrônicas. Nele irá conter várias informações que deverão ser inseridas nas planilhas para melhor descrição do equipamento. Ao final do cadastramento, o equipamento receberá uma identificação biunívoca no sistema SAP PM, composta por 9 caracteres, ou seja, não é permitida a duplicidade de equipamentos iguais no sistema e esse registro não pode ser apagado. O procedimento de cadastramento manual é formado por seis abas: geral, organização, localização, estrutura, rota e garantia, que devem ser preenchidas sequencialmente da esquerda para a direita. Nem todos os campos são obrigatórios; dependendo do tipo do equipamento, durante o preenchimento o sistema indica quais são.

A figura 14 ilustra a tela básica de cadastro do equipamento e a descrição de seus campos logo abaixo da figura.

Figura 14 - Dados gerais do cadastro do equipamento

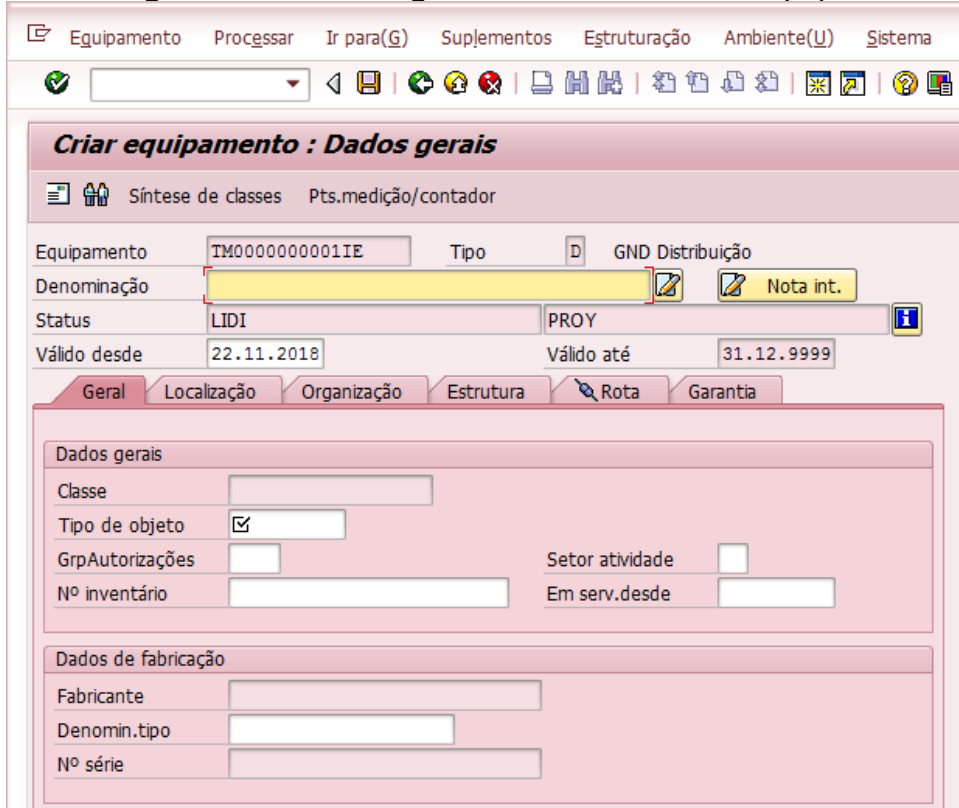

Fonte: Print screen da aplicação do sistema SAP PM. 
- Equipamento: Número que o SAP atribui automaticamente ao equipamento.

- Denominação: Nome pela qual é reconhecida a instalação .

- Tipo: Define o tipo de ativo dentro dos ativos de Gás Natural.

- Status: Indica a localização (esquerda) e seu estado operativo (direita).

- Validade: Data de validade do equipamento.

- Classe: define a que família ele pertence com base na classificação estabelecida.

- Tipo de objeto: define a faixa de pressão em MPO que o equipamento está instalado;

- Setor atividade: Indica o tipo de rede a que pertence a instalação auxiliar.

- GrpAutorizações: Categoriza as sociedades em função das autorizações dos usuários.

- EmServDesde: campo informa a data que o equipamento entrou em serviço.

- Fabricante: Nome do fabricante.

- Denomin.tipo: Descrição do tipo.

- № série: Número de série do equipamento;

Por padrão, o SAP PM possui cinco status de manutenção para os equipamentos. A figura 15 ilustra as categorias de status possíveis. Apenas os equipamentos que se encontram em status "SERV" são passíveis de manutenção por definição do sistema.

Figura 15 - Status do equipamento

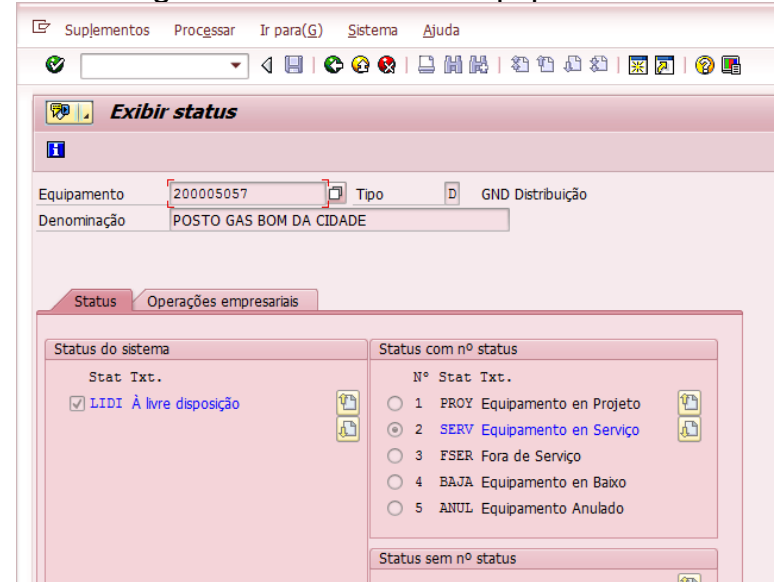

Fonte: Print screen da aplicação do sistema SAP PM. 
- PROY: Equipamentos encontram-se em fase de criação, não é possível realizar ou programar manutenção;

- SERV: Equipamentos estão disponíveis no sistema para manutenção;

- FSER: Equipamentos encontram-se fora de serviço, neste status é permitido o retorno para o status em serviço;

- Baja: Equipamento em Baixa no sistema, nesse status não é permitido o retorno do equipamento obsoleto para o status em serviço;

- ANUL: Equipamentos encontram-se anulados, significada que o cadastramento foi anulado.

Durante a fase de implantação, o cadastramento dos equipamentos foi realizado por meio da importação de planilhas eletrônicas. Foram catalogados mais de 20.000 equipamentos (válvulas de redes, estações reguladoras de pressão, elementos de proteção catódica, redes de distribuição de gás natural), distribuídos em mais de 50 planilhas eletrônicas. Cada equipamento foi cadastrado conforme a sua classe de manutenção preestabelecida.

\subsubsection{Subequipamentos}

O sistema permite que os equipamentos possuam subequipamentos ligados a eles, como mostra a figura 16, que ilustra uma estação de regulagem composta por seus subequipamentos: filtro, válvulas de bloqueio de entrada e saída, regulador ativo, regulador monitor, válvula de bloqueio automático, etc.

Figura 16 - Lista de estrutura de subequipamentos

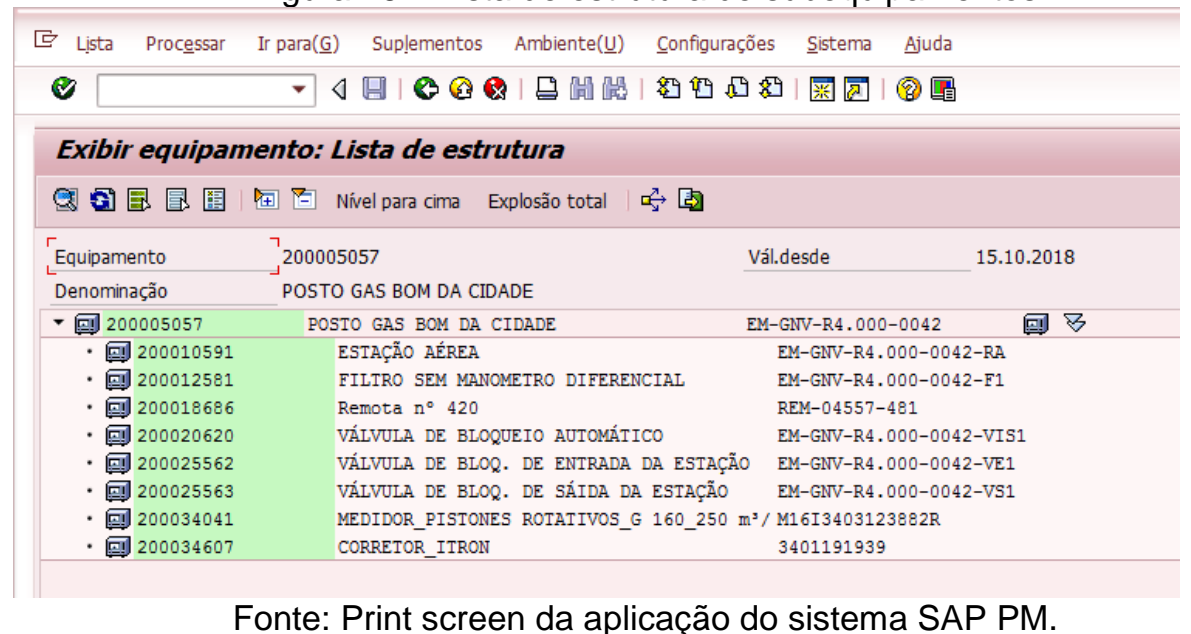

Fonte: Print screen da aplicação do sistema SAP PM. 


\subsubsection{Classe de equipamentos}

Foram definidas 47 classes com base no inventário dos equipamentos na GBM. Na figura 18 observam-se as classes dos equipamentos existentes. Essas classes têm o objetivo de propiciar uma gestão da manutenção de forma estruturada em função das suas características técnicas e físicas.

Figura 17 - Classe de Equipamento

\begin{tabular}{|c|c|c|c|c|c|}
\hline \multicolumn{5}{|l|}{ E No classe (1) 47 Entradas encontradas } & $-x$ \\
\hline Procurar por palavra-chave & \multicolumn{2}{|c|}{ Procurar por $\mathrm{n}^{0} \mathrm{cla} . .}$. & & 4 & 모 \\
\hline \multicolumn{6}{|l|}{$\nabla$} \\
\hline 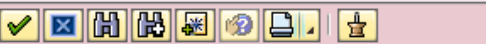 & \multirow{3}{*}{ Idio... } & \multirow[b]{2}{*}{ Tp. } & \multirow[b]{2}{*}{ Classe } & & \\
\hline Palavra-chave & & & & & \\
\hline COMPRESSOR & & 002 & COM & & $\Delta$ \\
\hline CONTROLE DE LACRES & PT & 002 & LAC & & $\boldsymbol{\nabla}$ \\
\hline CON - TUBO CAMISA & PT & 002 & 557 & & \\
\hline CONVERSORES & PT & 002 & CNV & & \\
\hline CROMATÓGRAFOS & PT & 002 & CRO & & \\
\hline DCAD - DRENO DISCRIMINADOR AC & PT & 002 & 542 & & \\
\hline DDCA - DRENAGEM DIRETA AC & PT & 002 & 541 & & \\
\hline DFA - CORRENTE IMPRESSA & PT & 002 & 610 & & \\
\hline DRC - RETORNO CORRIENTE & PT & 002 & 620 & & \\
\hline ELÉTRODO REFERÊNCIA DC & PT & 002 & 564 & & \\
\hline ESTAÇÃO DE MEDIÇÃO & PT & 002 & 220 & & \\
\hline ESTAÇÃO DE REGULAGEM COM OU SEM MEDIÇÃO & PT & 002 & 210 & & \\
\hline FILTRO COM MANÔMETRO DIFERENCIAL & PT & 002 & FL1 & & \\
\hline FILTRO COM MANÔMETRO DIFERENCIAL & PT & 002 & $\mathrm{FL} 2$ & & \\
\hline FILTRO EM "Y" & PT & 002 & $\mathrm{FL} 3$ & & \\
\hline INSTALAÇÃO COM DATA-LOGGER & PT & 002 & DTL & & \\
\hline INSTALAÇÃO REMOTA & PT & 002 & RTU & & \\
\hline MAN - DRENAGEM & PT & 002 & 560 & & \\
\hline MEDIDOR & PT & 002 & $\mathrm{CON}$ & & \\
\hline PAGO MENSUAL DE SERVICIOS & PT & 002 & PAG & & \\
\hline PLANTA SATÉLITE GÁS NATURAL COMPRIMIDO & PT & 002 & GNC & & \\
\hline PLANTA SATÉLITE GÁS PROPANO & PT & 002 & GLP & & \\
\hline PONTO DE CONTROLE P.C. & PT & 002 & 510 & & 13 \\
\hline RECINTO AÉREO & PT & 002 & AER & & \\
\hline RECINTO_MEDIDOR & PT & 002 & COFRE & & \\
\hline RECINTO SUBTERRÂNEO/ENTERRADO/DEPÓSITO & PT & 002 & SUB & & \\
\hline REDE DE GÁS & PT & 002 & RED & & \\
\hline REGULADOR COM VIS & PT & 002 & RG2 & & \\
\hline REGULADOR DUPLO COM VIS & PT & 002 & RG3 & & \\
\hline REGULADOR SEM VIS & PT & 002 & RG1 & & \\
\hline ROTA DE PINTURA & PT & 002 & PIN & & \\
\hline ROTA DE THT & PT & 002 & THT & & \\
\hline ROTA MANIOBRABILIDADE DE VÁLVULAS & PT & 002 & RVA & & \\
\hline TLG - TELEGESTÃO PC & PT & 002 & TLG & & \\
\hline TPL - TOMADA SIMPLES & PT & 002 & 550 & & \\
\hline TRANSMISSOR & PT & 002 & TRM & & \\
\hline TRECHO AÉREO & PT & 002 & TRA & & \\
\hline VÁLVULA AUXILIAR & PT & 002 & VAX & & \\
\hline VÁLVULA DE ALTA PRESSÃO A & PT & 002 & 910 & & \\
\hline VÁLVULA DE ESCAPE PARA A ATMOSFERA & PT & 002 & VEA & & \\
\hline VÁLVULA ESTAÇÃO REGULAGEM & PT & 002 & VER & & \\
\hline VÁLVULA INTERCEPTORA DE SEGURANÇA & PT & 002 & VIS & & \\
\hline VALVULAS DE SETOR - REDE 4-7 BAR & PT & 002 & 930 & & $\Delta$ \\
\hline ZONA MONITORAMENTO/RASTREAMENTO & PT & 002 & VIG & & 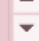 \\
\hline
\end{tabular}

47 Entradas encontradas

Fonte: Print screen da aplicação do sistema SAP PM. 


\subsubsection{Indicador ABC}

$O$ indicador $A B C$ é um código que determina a criticidade do equipamento. $O$ código $A B C$ define as frequências de manutenção, ou seja, se um equipamento deve ser inspecionado a cada semestre ou a cada ano. Isso irá depender de diversos fatores, como normativa interna, normas ABNT, histórico de falhas, entre outros. Foram criadas seis categorias distintas de criticidade para o indicador $A B C$ da GBM, sendo a categoria 1 a menos crítica e a categoria 6 a mais crítica.

\subsubsection{Pacotes de manutenção}

Os pacotes de manutenção são basicamente formados por um conjunto de rotinas que estabelecem os ciclos de repetição ou frequência de manutenção preventiva a que os equipamentos serão submetidos. Para criar os pacotes, utiliza-se a transação IP11. Na figura 18 há exemplos de pacotes cadastrados no SAP, que vão de uma operação a cada seis meses (6M) até uma operação a cada cinco anos $(5 A)$.

Figura 18 - Pacotes de manutenção

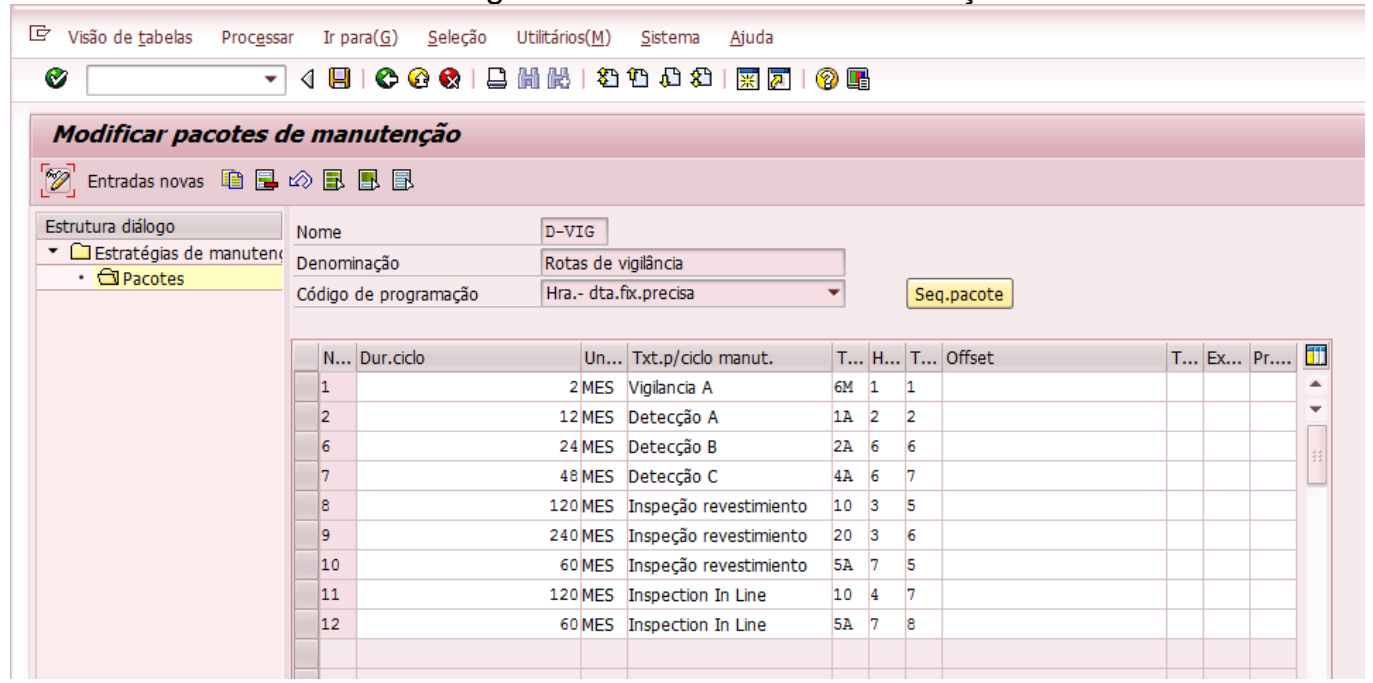

Fonte: Print screen da aplicação do sistema SAP PM.

\subsubsection{Listas de tarefas}

As listas de tarefas são responsáveis por definir as estratégias de manutenção para uma determinada classe, unindo a classe do equipamento com os pacotes de manutenção. Com isso se obtêm as operações básicas de 
manutenção preventiva que cada classe receber com suas respectivas frequências. A figura 19 apresenta um exemplo de uma lista de tarefas que contém duas atividades de manutenção cadastradas para os serviços de vigilância Tipo A com frequência semestral e detecção de escapamento com frequência anual.

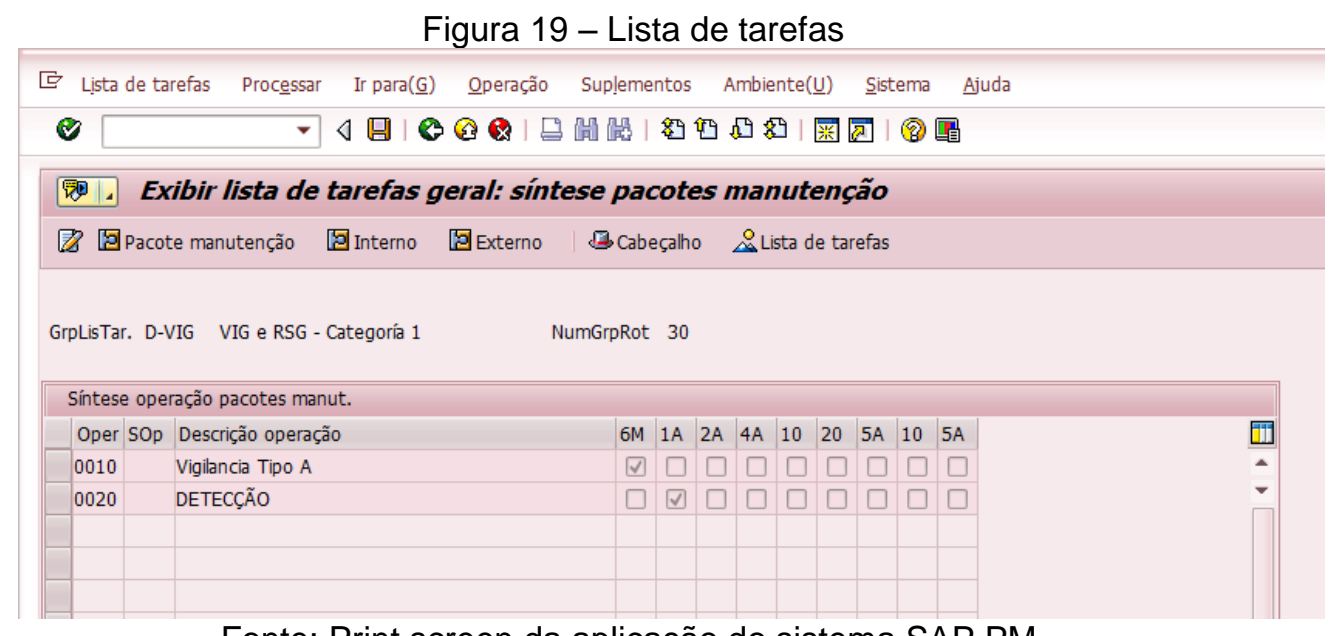

Fonte: Print screen da aplicação do sistema SAP PM.

\subsubsection{Planos de manutenção preventiva}

Os planos de manutenção são criados com base na classe do equipamento e seu respectivo código $\mathrm{ACB}$, pacotes de manutenção e listas de tarefas. Eles definem basicamente a data de início da manutenção, sua frequência de repetição, as atividades envolvidas nas tarefas a seres executadas e qual equipamento irá sofrear a intervenção. Para criar os planos utiliza-se a transação IP01 e para programá-los utiliza a transação IP10.

\subsection{Processo de detecção de escapamento de gás natural}

Para inspecionar e detectar possíveis escapamentos existentes nos gasodutos que compõem as redes e ramais de distribuição de gás natural, a empresa GBM utiliza procedimentos técnicos de manutenção com base em normativa interna e parâmetros legais dos órgãos reguladores que definem a frequência com que devem ser feitas as detecções de acordo com alguns critérios que serão explicados mais à frente. Ela também classifica os níveis de fuga e seus respectivos prazos de resolução, além de definir se um trecho do gasoduto deve ou não ser substituído. O processo de detecção de escapamento de gás nos gasodutos e ramais de distribuição enterrados é executado basicamente por 
operadores que caminham em campo sobre a geratriz superior das tubulações com mapas cartográficos de precisão submétrica, portando um equipamento digital, capaz de detectar e medir vazamento de gás metano na ordem de PPM.

Caso a quantidade de metano ultrapasse 60 partes por milhão, o detector liga um alarme sonoro caracterizando um vazamento; a partir daí o trabalhador responsável registra a localização exata em uma planta cartográfica que contém o traçado do gasoduto cuja medição ultrapassou o limite de metano. Após a detecção da região do escapamento, é necessário localizar a posição exata da fuga no gasoduto.

Devido ao fato de a tubulação estar enterrada, o gás que escapou gera sob o solo acúmulos por infiltração, então a região não necessariamente é a mesma do defeito. Desta forma, são feitos furos com uma broca especial sobre a geratriz superior da tubulação, e com a utilização de uma sonda de alta precisão é possível medir a concentração do gás metano. Normalmente onde estiver mais concentrado é onde o defeito está localizado.

Através do processo de detecção de escapamento, é possível manter o controle de estanqueidade de toda a rede, evitando acidentes envolvendo o gás natural e minimizando as perdas humanas e financeiras.

\subsubsection{Gestão da manutenção do processo de detecção de gás natural antes da implantação do sistema SAP PM}

Antes da implantação do SAP PM, a gestão, análise e controle do todo o processo de manutenção da detecção de escapamento de gás da empresa GBM era realizado por meio de planilhas eletrônicas e banco de dados baseado em arquitetura Visual Basic.

As informações eram descentralizadas, ou seja, cada setor da manutenção dispunha de um banco de dados próprio. Isso gerava várias bases de dados distintas com a mesma informação, por exemplo, era comum existir nomes de inventários diferentes para o mesmo equipamento.

Os formulários técnicos das visitas de manutenção preventiva e corretiva de campo eram emitidos todos os meses em formato físico (papel) e entregues manualmente para as empresas terceirizadas. Eventualmente alguns desses formulários eram extraviados e uma nova visita de manutenção era emitida. Não existia um controle de evidências por meio de fotos para comprovar a execução das atividades. 
As OT (ordens de trabalhos) eram emitidas individualmente por gasoduto, o que gerava um grande volume de OT por mês e demandava um controle pontual das atividades sem conexão entre elas, dificultando posteriormente a análise das informações de retorno da execução das OT.

Normalmente levava-se mais de 30 dias para se informar a conclusão das atividades de manutenção para o setor responsável pelo planejamento da manutenção. Isso impactava na demora da elaboração dos relatórios de acompanhamentos físicos de execução mensais, que eram emitidos todo quinto dia útil do mês subsequente ao planejado.

Não existia o controle do acompanhamento das atividades por meio de relatórios digitais no final de cada ciclo de manutenção.

O plano de manutenção era elaborado todos os anos manualmente, em formato físico, normalmente no mês de junho, e levava-se em torno de 30 dias para conclusão do mesmo com uma equipe composta por seis colaboradores. Ele era elaborado utilizando a diferente base de dados dos ativos e os inventários dos equipamentos e base nas frequências de manutenção da normativa interna do grupo GBM.

\subsubsection{Gestão da manutenção do processo de detecção de gás após implantação do sistema SAP PM}

Um dos principais objetivos do projeto de implantação do sistema SAP PM em âmbito corporativo foi a necessidade de consolidar e otimizar não só o processo de detecção de escapamento, mas os planos de todos os equipamentos auxiliares de rede, além de funcionar como um grande repositório de informações técnicas. O SAP PM é uma ferramenta capaz de unificar as diversas fontes de dados relacionadas à gestão da manutenção em uma única base de dados. Os benefícios qualitativos são:

- Otimização das atividades de manutenção com base em melhores práticas;

- Repositório único dos ativos de transporte e distribuição de gás;

- Sistema único para gestão e registro de manutenção em todas as vertentes;

- Melhoria na gestão com as empresas colaboradoras.

- Possibilidade de conexão com outros sistemas corporativos;

- Possibilidade de implantação de mobilidade; 
- Análise homogênea da manutenção a nível de instalações;

- Homogeneização dos critérios de manutenção;

- Agilização caso existam mudanças de critérios; e

- Facilitação da análise da eficiência do processo de manutenção através do comparativo de resultados.

Um dos benefícios obtidos com a implantação do SAP PM foi a gestão, análise e controle do todo o processo de manutenção da detecção de escapamento realizada de forma sistemática. Os relatórios passaram a ser emitidos automaticamente por meio das transações IW39 e IW 69.

Outro benefício obtido foi a unificação do cadastro dos equipamentos em uma única base de dados, acessível a qualquer colaborador da empresa, desde que habilitado para operar o sistema. Foi importada a cartográfica das redes de distribuição, e a partir dessa base foram criadas rotas de detecção de manutenção. Cada rota é formada por diversos gasodutos que formam uma rede de distribuição, a figura 20 ilustra um exemplo da estrutura das rotas de detecção.

Figura 20 - Rotas de manutenção

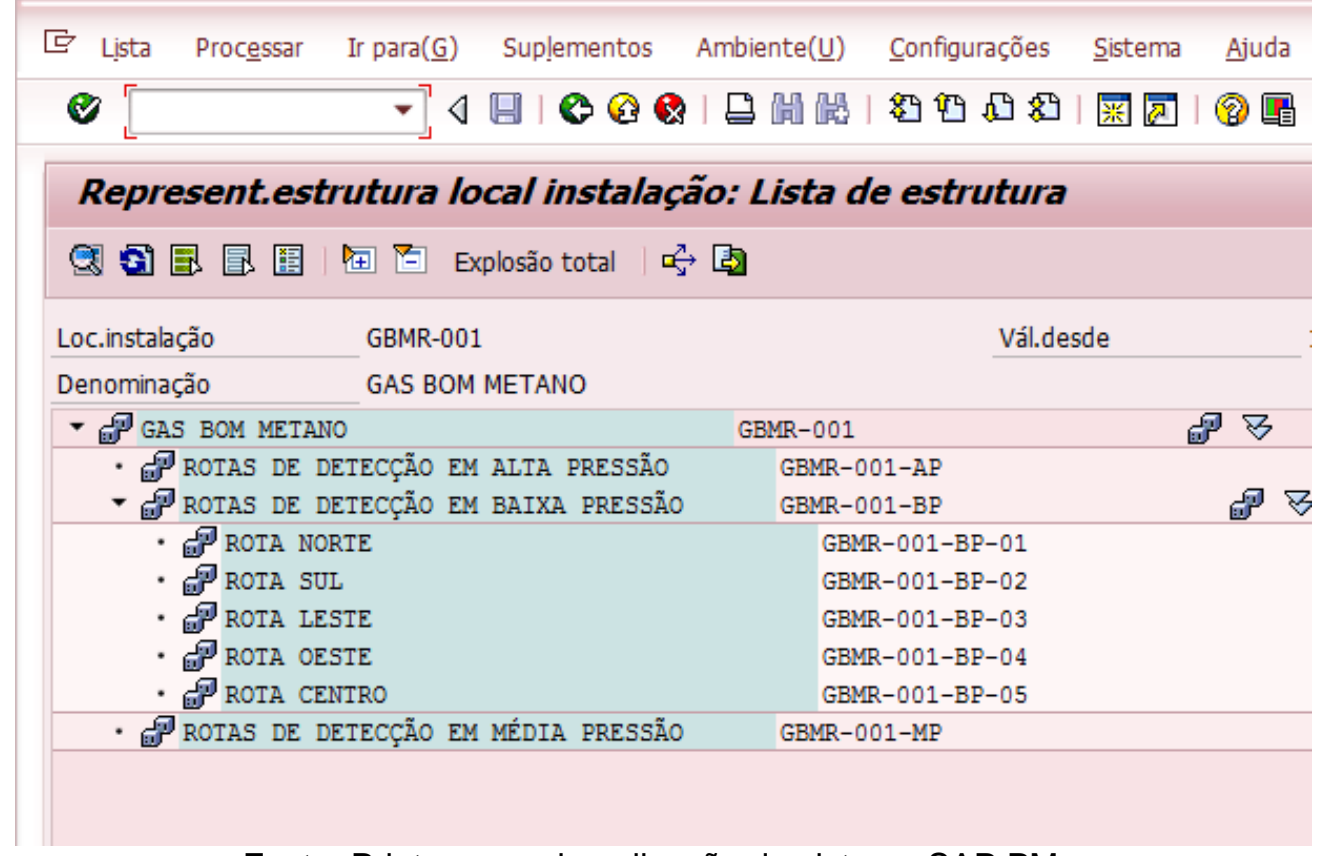

Fonte: Print screen da aplicação do sistema SAP PM.

Essas rotas possibilitaram a otimização da análise dos resultados das rotinas de manutenção pelo setor de gestão da manutenção.

Outro aspecto importante foi a possibilidade de relatar os defeitos detectados durante as visitas de manutenção preventiva no fechamento técnico no sistema. As notas de manutenção corretiva por definição possuem prazos 
normativos para sua resolução, sendo três meses para defeitos mecânicos e 12 meses para defeitos de infraestrutura. A figura 21 mostra a criação de uma nota de manutenção través da transação IW21.

Figura 21 - OT Corretiva

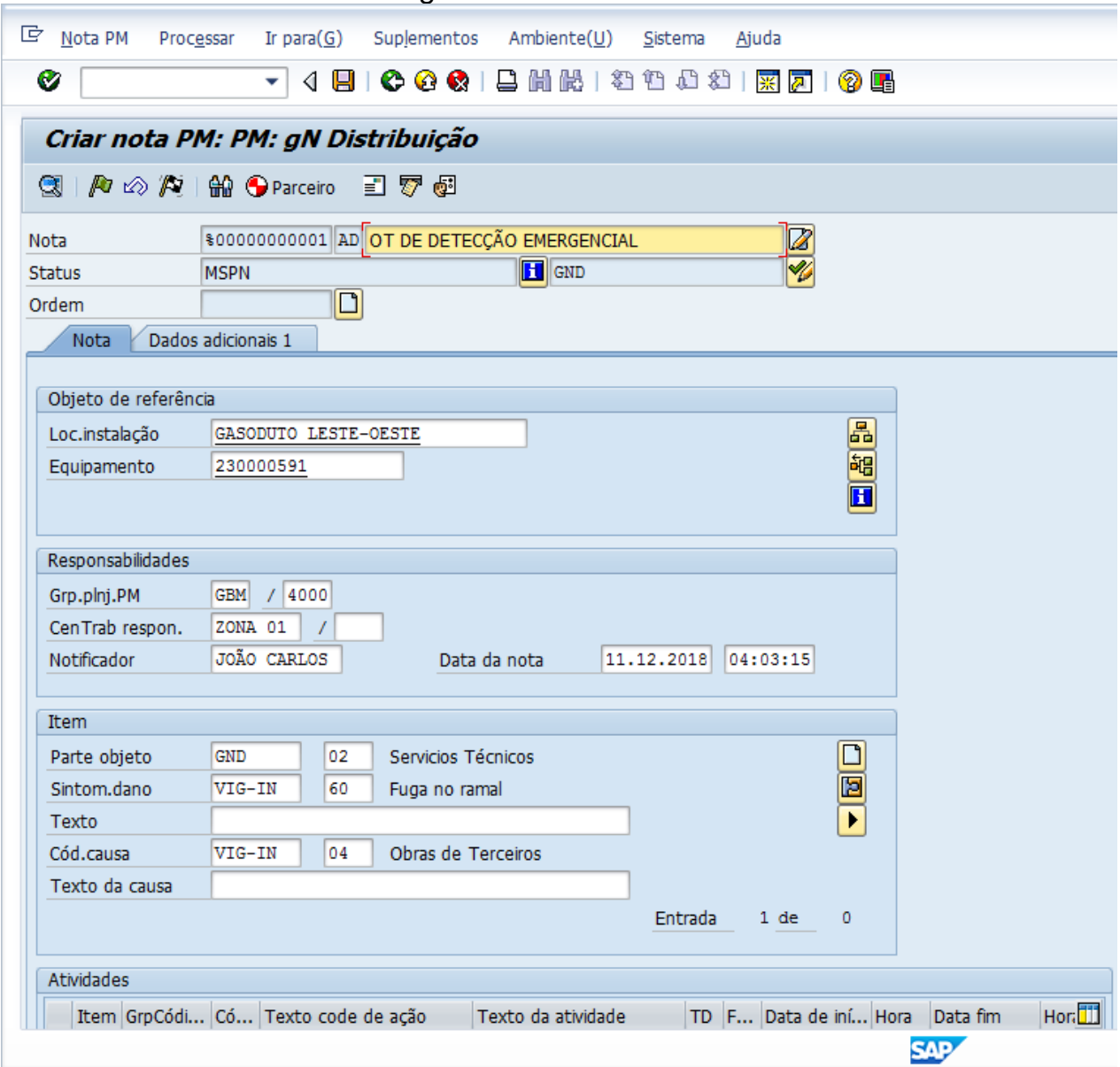

Fonte: Print screen da aplicação do sistema SAP PM.

Houve um ganho na consolidação das informações contidas nos formulários além da melhoria da integridade dos dados. No fechamento técnico também é possível anexar relatórios de execução, fotos, e-mail em formato digital, o que proporciona uma confiabilidade maior à veracidade das informações. Utilizando a transação IW33 é possível visualizar as evidências da conclusão dos serviços.

A figura 22 ilustra um relatório da situação das ordens de trabalho emitidas utilizando a transação IW39. Cada linha representa uma rota de inspeção. Na coluna "status", o termo "fechado" indica que a OT foi concluída, por outro lado o termo "aberto" indica que ainda está em execução. As colunas "data planejada" e "data fechamento" contêm as datas de emissão e conclusão da OT. As colunas "km previsto" e "km reais" contêm o lançamento da extensão realizada em km que foi detectada na rota. Com essas melhorias se obteve um ganho na velocidade de 
elaboração dos relatórios gerenciais de acompanhamento de execução das atividades.

Figura 22 - Lista da situação atual das ordens

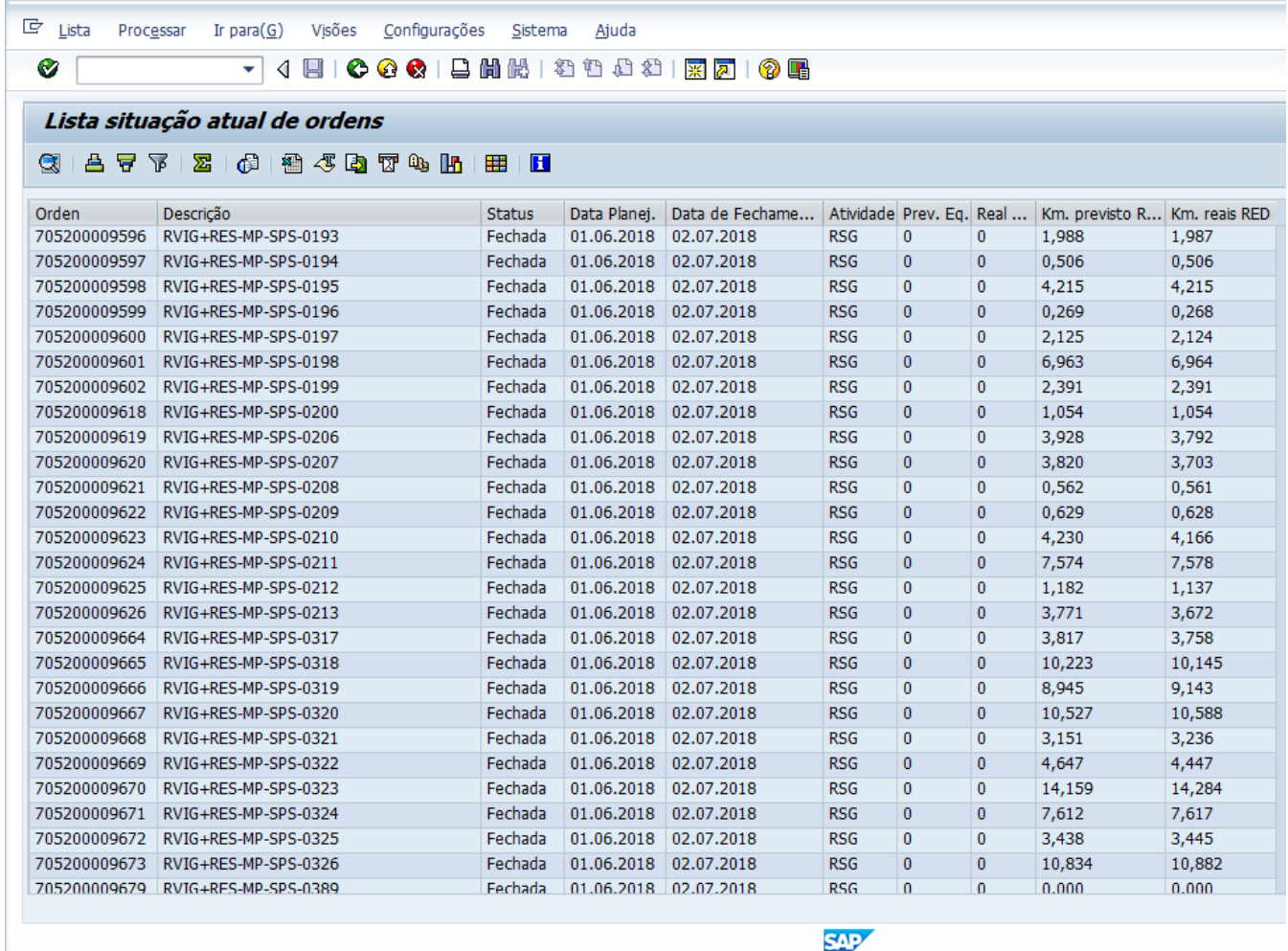

Fonte: Print screen da aplicação do sistema SAP PM.

Os planos anuais de manutenção do processo de detecção foram automatizados, ou seja, uma vez programados com base nas rotas existentes e normativa do grupo GBM, eles repetem utilizando as informações de alimentação do sistema. A figura 23 ilustra a tela da transação IP 10 com a projeção de um plano de manutenção com frequência semestral de inspeção, projetado para dois anos. 
Figura 23 - Projeção do plano de manutenção

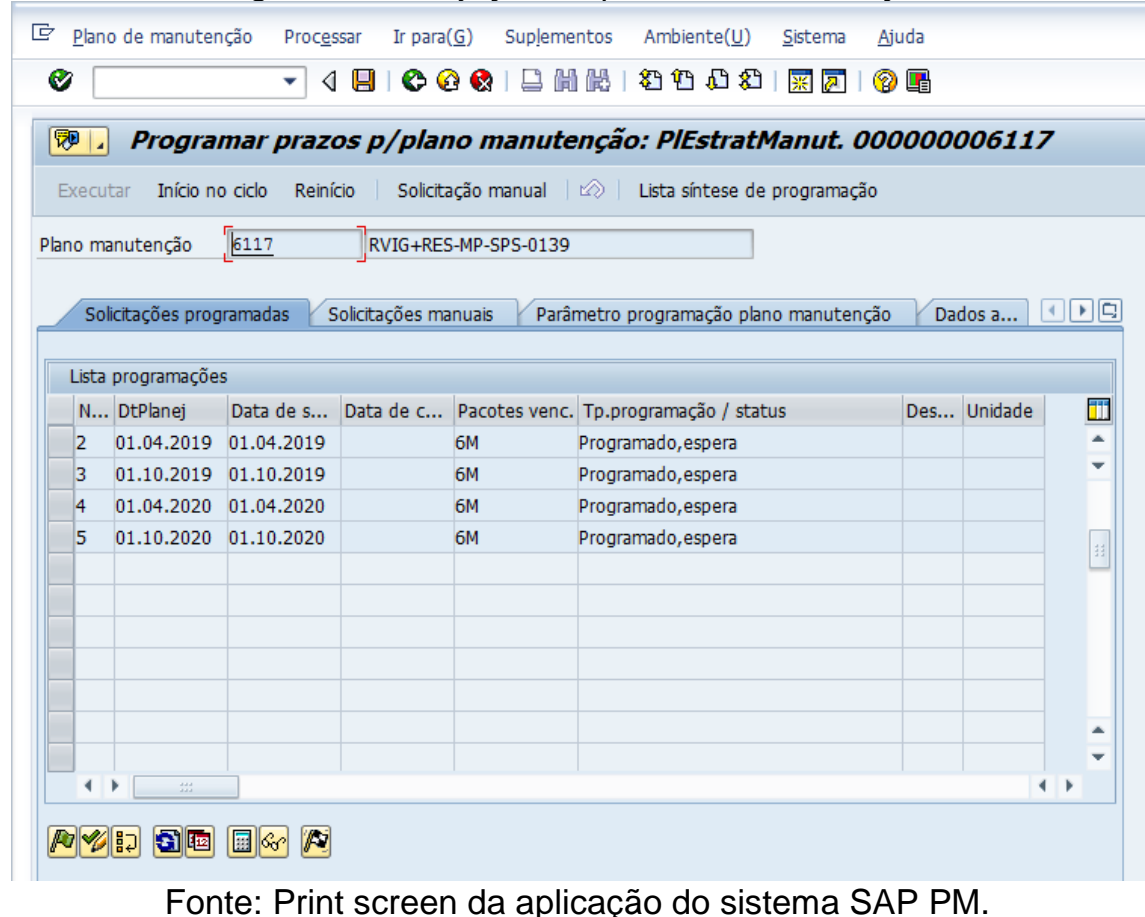

\subsubsection{Indicadores de desempenho}

Para medir os possíveis benefícios proporcionados com implantação do sistema SAP PM em comparação ao processo anterior, foi criado um indicador de desempenho chamado "quantidade de fugas detectada por $\mathrm{km}$ de rede acumuladas em um período de um ano" (NF/km.Ano).

O sistema SAP PM entrou em operação em setembro de 2017. O processo foi medido por um período de 12 meses. Para comparar os processos antes e pós a implantação, foi utilizada uma amostra de dados a partir de setembro de 2015 , tendo como objetivo mostrar a evolução do processo por um período de 36 meses: 24 meses antes da implantação e 12 meses após a implantação. Neste período foram coletadas as informações das ordens de serviço referentes às fugas detectadas e posteriormente tabuladas em uma planilha em Excel. A figura 24 mostra um exemplo dos dados tabulados durante os 36 meses. 
Figura 24 - Lista dos dados tabulados das fugas

\begin{tabular}{|c|c|c|c|c|c|c|c|c|c|}
\hline №DA FUC - & № DO PEDIC V & LOGRADOUF - & NÍV V LOCALIZAÇÃO & - DIÂMETF - & PRESSÂ - & MATERIA = & TIPO DE G I & DATA DA CONFIRMAÇÂ $=$ & DATA DO REPAF \\
\hline 18IEC0155 & DT36618 & AVENIDA & 1 Válvulas & 100 & AP & $A C$ & GN & 13-set-18 & $13 / 09 / 2018$ \\
\hline 18IEC0156 & DT36618 & ESTRADA & 1 Válvulas & 350 & AP & $A C$ & GN & $13-$ set-18 & $13 / 09 / 2018$ \\
\hline 18IEC0116 & DT31318 & RUA & 2 Corpo da Tubulação & 75 & BP & $A C$ & GN & 16-ago-18 & $15 / 09 / 2018$ \\
\hline 18IEC0154 & DT36618 & RUA & 1 Válvulas & 350 & AP & $A C$ & GN & 13-set-18 & $13 / 09 / 2018$ \\
\hline 18NIP0239 & DT16718 & RUA & 1 Válvulas & 150 & AP & $A C$ & GN & 12 -set-18 & $12 / 09 / 2018$ \\
\hline 18NIP0240 & DT16718 & FAIXA & 1 Válvulas & 150 & AP & $A C$ & GN & $13-$ set-18 & $13 / 09 / 2018$ \\
\hline 18NIP0241 & DT16718 & RODOVIA & 1 Válvulas & 150 & AP & AC & GN & 13 -set-18 & $13 / 09 / 2018$ \\
\hline 18NIP0233 & DT16518 & AVENIDA & 1 Válvulas & 350 & AP & $A C$ & GN & 19-ago-18 & $19 / 08 / 2018$ \\
\hline 18NIP0235 & DT17218 & ESTRADA & 1 Válvulas & 200 & AP & $A C$ & GN & 19-ago-18 & $19 / 08 / 2018$ \\
\hline 18IEC0065 & DT18418 & RUA & 2 Corpo da Tubulação & 250 & BP & $A C$ & GN & 10-jun-18 & $21 / 08 / 2018$ \\
\hline 18IEC0066 & DT18418 & RUA & 2 Corpo da Tubulação & 250 & BP & $A C$ & GN & 10-jun-18 & $21 / 08 / 2018$ \\
\hline 18NIP0257 & DT17218 & RUA & 1 Válvulas & 200 & AP & $A C$ & GN & 18-ago-18 & $18 / 08 / 2018$ \\
\hline 18NIP0234 & DT17218 & ESTRADA & 1 Válvulas & 200 & AP & $A C$ & GN & 19-ago-18 & $19 / 08 / 2018$ \\
\hline 18NIP0230 & DT27018 & RUA & 1 Válvulas & 100 & AP & $A C$ & GN & 18-ago-18 & $18 / 08 / 2018$ \\
\hline 18IEC0132 & DT33218 & AVENIDA & 1 Válvulas & 150 & AP & $A C$ & GN & 23-ago-18 & $23 / 08 / 2018$ \\
\hline 18IEC0074 & DT22818 & RUA & 2 Conexão T de serviço & 225 & BP & $A C$ & GN & 04-jul-18 & $16 / 08 / 2018$ \\
\hline 18IEC0079 & DT22918 & RUA & 2 Conexão $T$ de serviço & 100 & BP & $A C$ & GN & 03-jul-18 & $15 / 08 / 2018$ \\
\hline 18IEC0138 & AT34918 & RUA & 2 Corpo da Tubulação & 150 & BP & $A C$ & GN & 25-ago-18 & $28 / 08 / 2018$ \\
\hline 18IEC0139 & АТЗ4918 & RUA & 2 Corpo da Tubulação & 150 & BP & $A C$ & GN & 25-ago-18 & $28 / 08 / 2018$ \\
\hline 18NIP0231 & DT27018 & AVENIDA & 1 Válvulas & 200 & AP & $A C$ & GN & 17-ago-18 & $17 / 08 / 2018$ \\
\hline 18IEC0131 & DT27218 & ESTRADA & 1 Válvulas & 150 & MP & $A C$ & GN & 22-ago-18 & $22 / 08 / 2018$ \\
\hline 18NIP0232 & DT16518 & AVENIDA & 1 Válvulas & 350 & AP & $A C$ & GN & 19-ago-18 & $21 / 08 / 2018$ \\
\hline 18NIP0236 & DT17218 & PONTE & 1 Válvulas & 200 & AP & $A C$ & GN & 18-ago-18 & $18 / 08 / 2018$ \\
\hline 18NIP0211 & DT16218 & AVENIDA & 1 Válvulas & 200 & AP & $A C$ & GN & 13-jul-18 & $13 / 07 / 2018$ \\
\hline 18NIP0099 & DT10518 & RUA & 2 Válvulas & 50 & MP & $A C$ & GN & 18-abr-18 & $09 / 07 / 2018$ \\
\hline 18NIP0108 & DT10518 & AVENIDA & 2 Válvulas & 50 & MP & $A C$ & GN & 18-abr-18 & $09 / 07 / 2018$ \\
\hline 18NIP0109 & DT10518 & AVENIDA & 2 Válvulas & 50 & MP & $A C$ & GN & 18-abr-18 & 09/07/2018 \\
\hline 18NIP0134 & DT10918 & RUA & 2 Corpo da Tubulação & 75 & BP & $A C$ & GN & 19-abr-18 & $14 / 06 / 2018$ \\
\hline 18NIP0091 & DT10218 & RUA & 2 Conexão $T$ de serviço & 150 & BP & $A C$ & GN & $05-a b r-18$ & $19 / 06 / 2018$ \\
\hline 18IEC0059 & DT17518 & RUA & 1 Válvulas & 350 & AP & $A C$ & GN & 12-mai-18 & $12 / 05 / 2018$ \\
\hline 18NIP0154 & DT16418 & AVENIDA & 1 Válvulas & 150 & AP & $A C$ & GN & 11-mai-18 & $11 / 05 / 2018$ \\
\hline 18IEC0061 & DT17518 & RUA & 1 Válvulas & 100 & AP & $A C$ & GN & 13-mai-18 & $13 / 05 / 2018$ \\
\hline 18IEC0060 & DT17518 & PRAÇA & 1 Válvulas & 350 & AP & $A C$ & GN & 12 -mai-18 & $12 / 05 / 2018$ \\
\hline 18NIP0153 & DT16418 & RUA & 1 Válvulas & 75 & AP & $A C$ & GN & 08-mai-18 & $08 / 05 / 2018$ \\
\hline 18NIP0155 & DT16818 & RODOVIA & 1 Válvulas & 50 & AP & $A C$ & GN & 14-mai-18 & $14 / 05 / 2018$ \\
\hline 18IEC0057 & DT15418 & RUA & 1 Válvulas & 75 & MP & $A C$ & GN & $07-m a i-18$ & $07 / 05 / 2018$ \\
\hline 18NIP0092 & DT10618 & ESTRADA & 2 Válvulas & 50 & MP & $A C$ & GN & 06-abr-18 & $10 / 05 / 2018$ \\
\hline 18NIP0102 & DT10518 & RUA & 2 Válvulas & 75 & MP & $A C$ & GN & 18-abr-18 & $11 / 05 / 2018$ \\
\hline 18NIP0104 & DT10518 & RUA & 2 Válvulas & 50 & MP & $A C$ & GN & 18-abr-18 & $16 / 05 / 2018$ \\
\hline 18NIP0106 & DT10518 & RUA & 2 Válvulas & 50 & MP & $A C$ & GN & 18-abr-18 & $24 / 05 / 2018$ \\
\hline 18IEC0058 & DT17518 & RUA & 1 Válvulas & 150 & AP & $A C$ & GN & 12 -mai-18 & $12 / 05 / 2018$ \\
\hline 18IEC0044 & DT09418 & ESTRADA & 2 Válvulas & 150 & MP & $A C$ & GN & 13-abr-18 & $12 / 05 / 2018$ \\
\hline 18NIP0044 & DT08318 & RUA & 2 Válvulas & 250 & BP & $A C$ & GN & 06-mar-18 & $11 / 04 / 2018$ \\
\hline 18IEC0028 & DT06818 & RUA & 2 Corpo da Tubulação & 100 & BP & $A C$ & GN & 12-mar-18 & $14 / 04 / 2018$ \\
\hline
\end{tabular}

Fonte: Elaborada pelo autor.

Com base no parâmetro normativo do órgão regulador, que cita os patamares de confiabilidade de rede, foram selecionadas cinco redes de distribuição de gás natural com pressão igual ou inferior a 4 bar, localizadas em região urbana, com histórico de fuga igual ou superior 1 NF/ km.Ano em 2015 para objeto do estudo. As tabelas 9, 10 e 11 apresentam as redes com suas respectivas exenções em quilômetros, quantidade de fugas acumuladas no período de 12 meses e o índice de NF/km.Ano a partir de setembro de 2015.

Tabela 9 - NF/km.Ano no período entre 01/09/2015 e 30/08/2016

\begin{tabular}{|c|c|c|c|c|c|}
\hline Rede & $\begin{array}{c}\text { Material } \\
\text { Predominante }\end{array}$ & $\begin{array}{l}\text { Diâmetro } \\
(\mathrm{mm})\end{array}$ & $\begin{array}{c}\text { Quantidade } \\
\text { Fugas }\end{array}$ & $\begin{array}{c}\text { Extensão } \\
(\mathbf{k m})\end{array}$ & NF/km.Ano \\
\hline LESTE I & $\mathrm{AÇO}$ & 100 & 88 & 41,44 & 2,12 \\
\hline LESTE II & AÇO & 150 & 81 & 11,29 & 7,17 \\
\hline OESTE & $\mathrm{PE}$ & 90 & 70 & 43,90 & 1,59 \\
\hline NORTE I & $\mathrm{PE}$ & 90 & 37 & 37,92 & 0,98 \\
\hline NORTE II & $\mathrm{PE}$ & 110 & 33 & 45,95 & 0,72 \\
\hline
\end{tabular}

Fonte: Elaborada pelo autor. 
Na tabela 9 observa-se que as redes Leste I, Leste II e Oeste obtiveram índices superiores a $1 \mathrm{NF} / \mathrm{km}$.Ano, com material em aço carbono.

Tabela 10 - Índice NF/km.Ano período entre 01/09/2016 e 30/08/2017

\begin{tabular}{|c|c|c|c|c|c|}
\hline Rede & $\begin{array}{c}\text { Material } \\
\text { Predominante }\end{array}$ & $\begin{array}{c}\text { Diâmetro } \\
(\mathbf{m m})\end{array}$ & $\begin{array}{c}\text { Quantidade } \\
\text { Fugas }\end{array}$ & $\begin{array}{c}\text { Extensão } \\
(\mathbf{k m})\end{array}$ & NF/km.Ano \\
\hline LESTE I & AÇO & 100 & 39 & 56,30 & 0,69 \\
\hline LESTE II & AÇO & 150 & 28 & 13,34 & 2,10 \\
\hline OESTE & PE & 90 & 42 & 56,57 & 0,74 \\
\hline NORTE I & PE & 90 & 21 & 48,32 & 0,43 \\
\hline NORTE II & PE & 110 & 51 & 58,91 & 0,87 \\
\hline
\end{tabular}

Fonte: Elaborada pelo autor.

Na tabela 10 observa-se que apenas a rede Leste I obteve um índice superior a $1 \mathrm{NF} / \mathrm{km}$.Ano.

Tabela 11 - Índice NF/km.Ano período entre 01/09/2017 e 30/08/2018

\begin{tabular}{|c|c|c|c|c|c|}
\hline Rede & $\begin{array}{c}\text { Material } \\
\text { Predominante }\end{array}$ & $\begin{array}{c}\text { Diâmetro } \\
\mathbf{( m m})\end{array}$ & $\begin{array}{c}\text { Quantidade } \\
\text { Fugas }\end{array}$ & $\begin{array}{c}\text { Extensão } \\
\mathbf{( k m )}\end{array}$ & NF/km.Ano \\
\hline LESTE I & AÇO & 100 & 48 & 66,60 & 0,72 \\
\hline LESTE II & AÇO & 150 & 8 & 17,67 & 0,45 \\
\hline OESTE & PE & 90 & 31 & 64,39 & 0,48 \\
\hline NORTE I & PE & 90 & 5 & 49,98 & 0,11 \\
\hline NORTE II & PE & 110 & 34 & 70,94 & 0,48 \\
\hline
\end{tabular}

Fonte: Elaborada pelo autor.

Na tabela 11 observa-se que após a implantação do SAP PM todas as redes estão situadas abaixo do patamar de confiabilidade recomendado pela agência reguladora de 1,0 NF/km.Ano.

Também podemos constatar que as redes sofreram expansão entre os anos de 2015 até 2018 , cerca de $24 \mathrm{~km}$ para a rede Leste I, $6 \mathrm{~km}$ para a rede Leste II, $20 \mathrm{~km}$ para a rede Oeste, $12 \mathrm{~km}$ para a rede Norte I, $25 \mathrm{~km}$ para a rede Norte II. Outro fato importante foi que as redes em aço carbono obtiveram os maiores índices de fuga, o que sugere deficiência no sistema de proteção catódica.

As figuras 25, 26, 27, 28 e 29 mostram a evolução da quantidade de fugas detectadas por mês. A linha vertical vermelha tracejada da esquerda para a direita indica o início do processo pós-implantação SAP PM. Observa-se uma queda das fugas detectadas, exceto na rede Leste I. A linha horizontal azul indica a meta do número de falhas por quilometro de rede detectado conforme a agência reguladora. As demais linhas horizontais indicam os índices NF/km médios obtidos no período pesquisado. 
Figura 25 - Lista dos dados tabulados das fugas

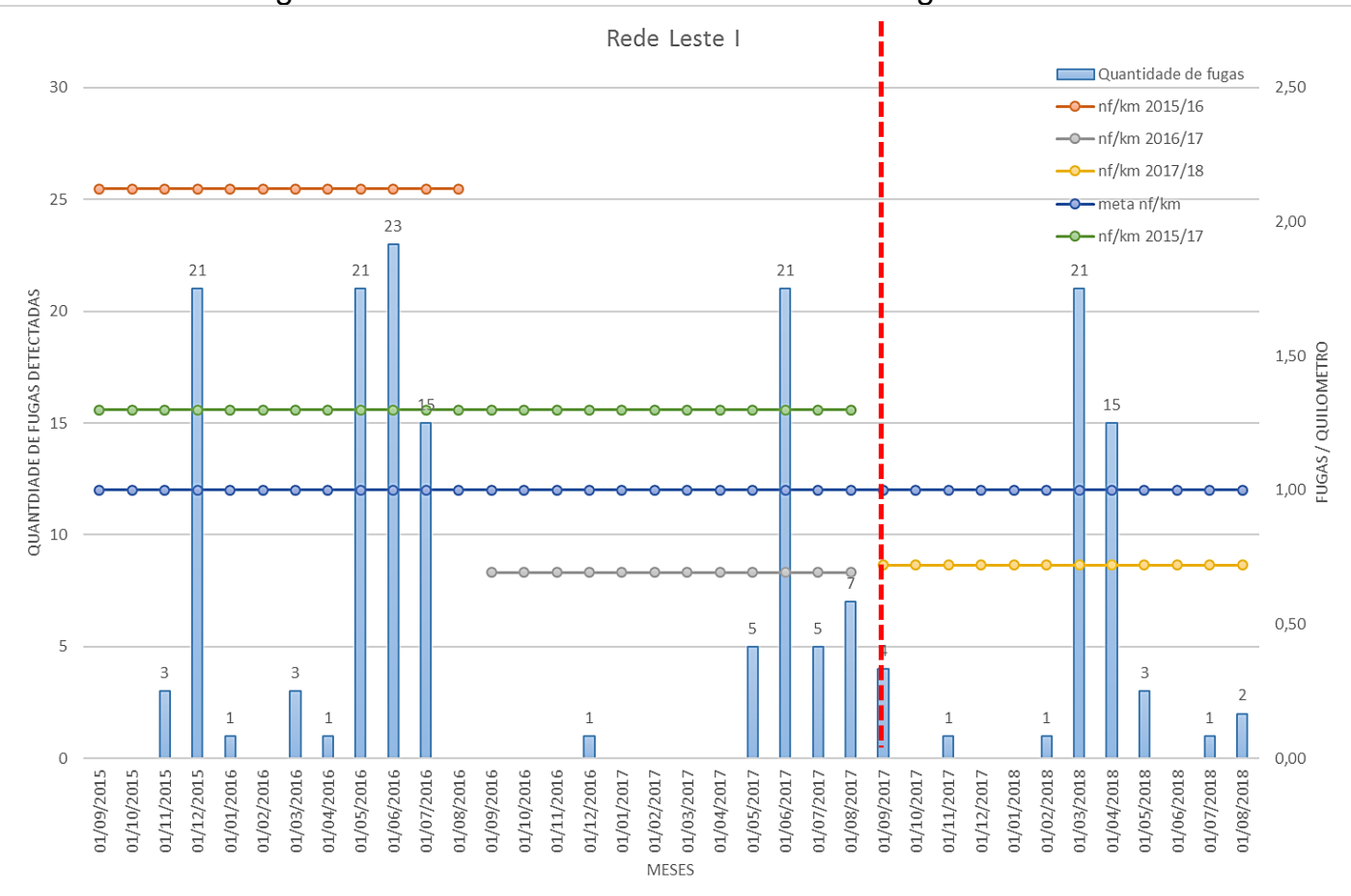

Fonte: Elaborada pelo autor.

Figura 26 - Quantidade de fugas detectadas por mês na rede Leste II

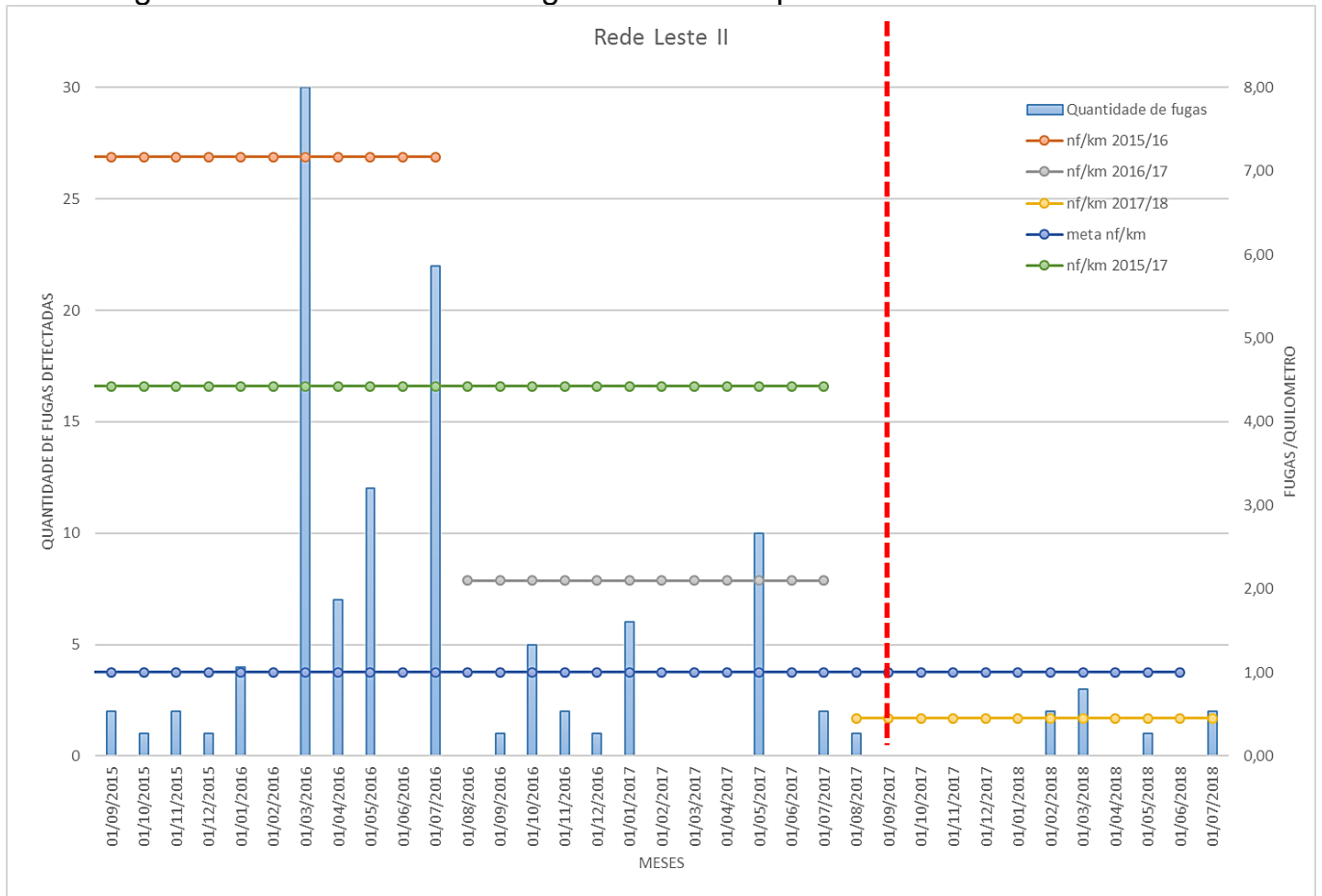

Fonte: Elaborada pelo autor. 
Figura 27 - Quantidade de fugas detectadas por mês na rede Oeste

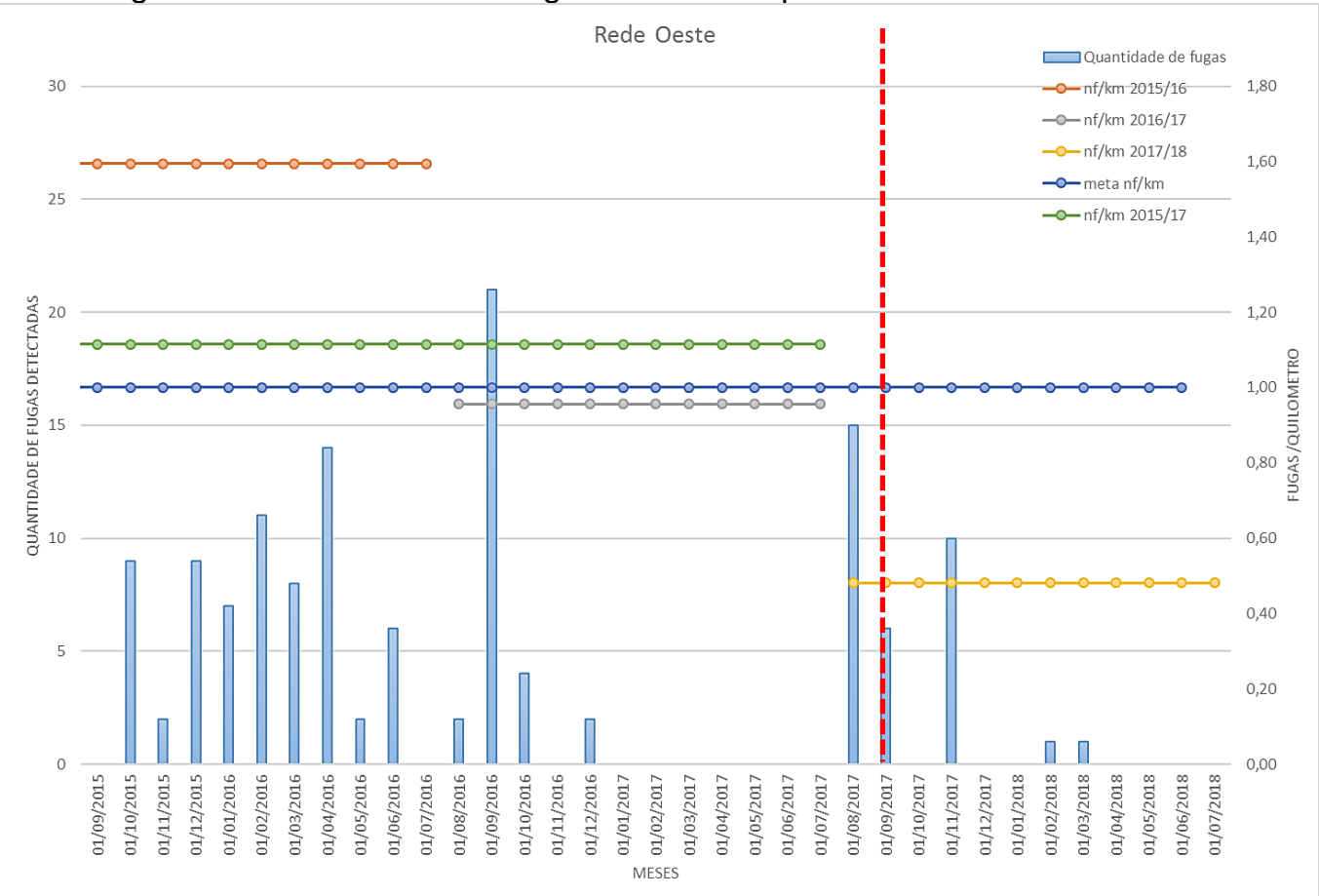

Fonte: Elaborada pelo autor.

Figura 28 - Quantidade de fugas detectadas por mês na rede Norte I

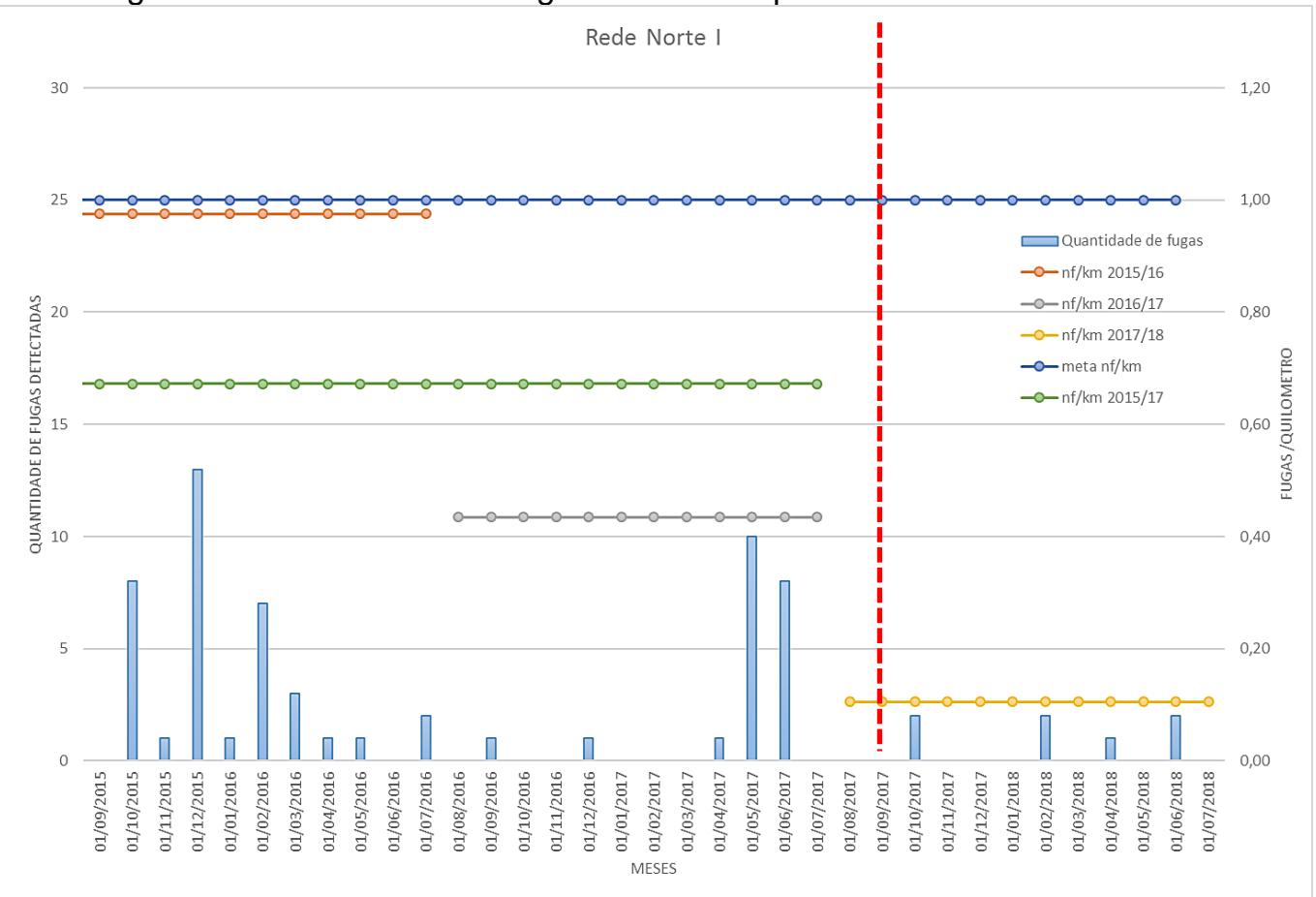

Fonte: Elaborada pelo autor. 
Figura 29 - Quantidade de fugas detectadas por mês na rede Norte II

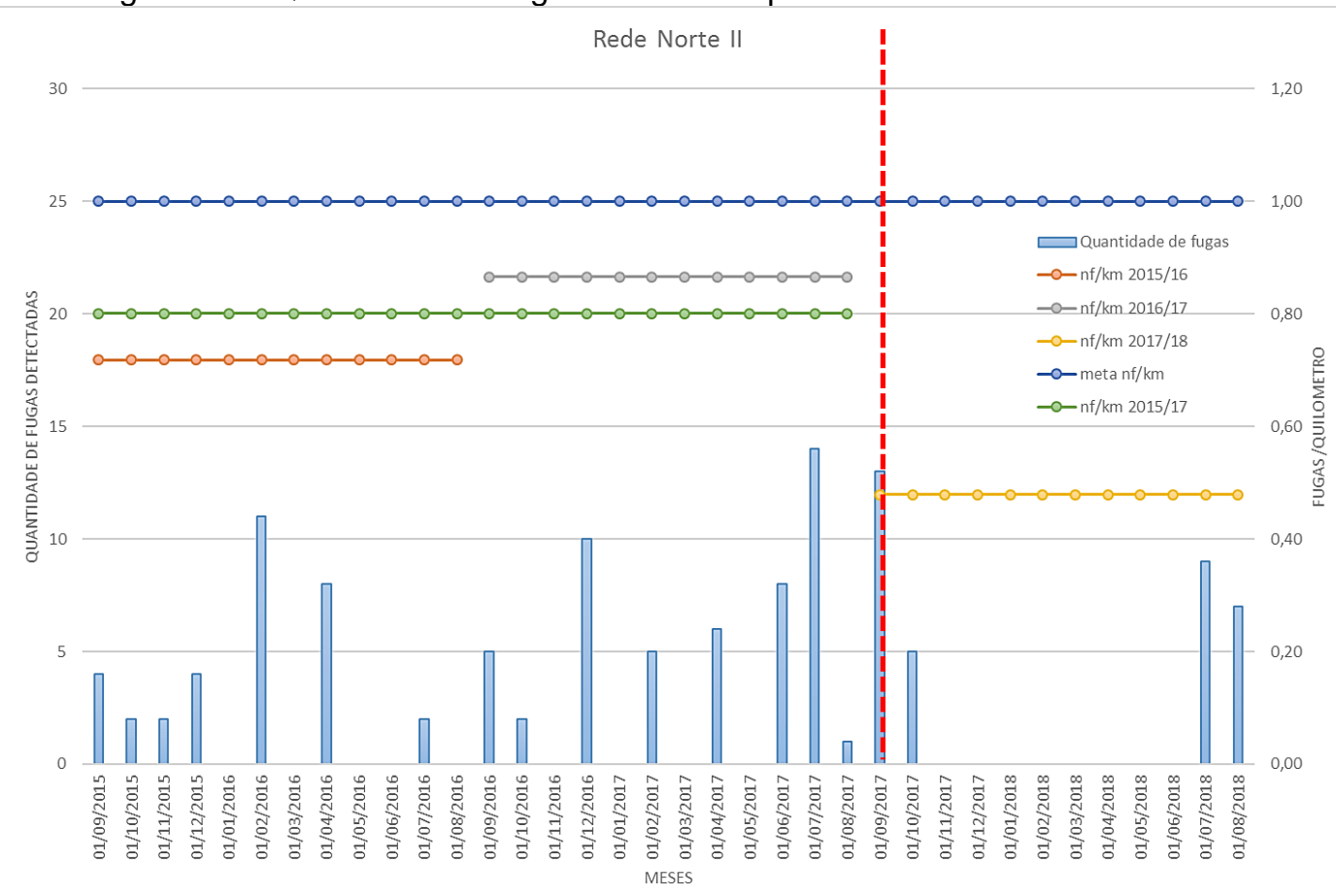

Fonte: Elaborada pelo autor.

A tabela 12 apresenta um resumo da quantidade de fugas detectadas entre o período de 2016/2018 (36 meses). Com base na tabela 12, observamos que se obteve um índice de fugas global de $0,90 \mathrm{NF} / \mathrm{km}$, ou seja, situou-se dentro do patamar de confiabilidade recomendado pela agência reguladora de 1,0 $\mathrm{NF} / \mathrm{km}$.Ano.

Tabela 12 - Índice NF/km.Ano Período entre 01/10/2015 e 30/09/2018

\begin{tabular}{|c|c|c|c|c|c|}
\hline Anos & $\begin{array}{c}\text { Material } \\
\text { Predominante }\end{array}$ & Diâmetro (mm) & Quat. Fugas & Extensão (km) & NF/kmAno \\
\hline $2015 / 2016$ & PE & $90,100,110$ e 150 & 309 & 180,51 & 1,71 \\
\hline $2016 / 2017$ & PE & $90,100,110$ e 150 & 181 & 233,45 & 0,78 \\
\hline $2017 / 2018$ & PE & $90,100,110$ e 150 & 126 & 269,58 & 0,44 \\
\hline \multicolumn{2}{|r|}{ Índice médio global das redes em 36 meses } & $\mathbf{6 1 6}$ & $\mathbf{6 8 3 , 5 4}$ & $\mathbf{0 , 9 0}$ \\
\hline
\end{tabular}

Fonte: Elaborada pelo autor.

A figura 30 mostra a evolução da quantidade de fugas detectadas acumulada de todas as redes no período de 36 meses. A linha vertical vermelha tracejada da esquerda para a direita indica o início do processo pós-implantação SAP PM. Observa-se uma queda das fugas detectadas. A linha horizontal azul indica a meta do número de falhas por quilometro de rede detectado conforme a agência reguladora. As demais linhas horizontais indicam os índices NF/km médios obtidos no período pesquisado. 
Figura 30 - Quantidade de fugas detectadas no período de 36 meses

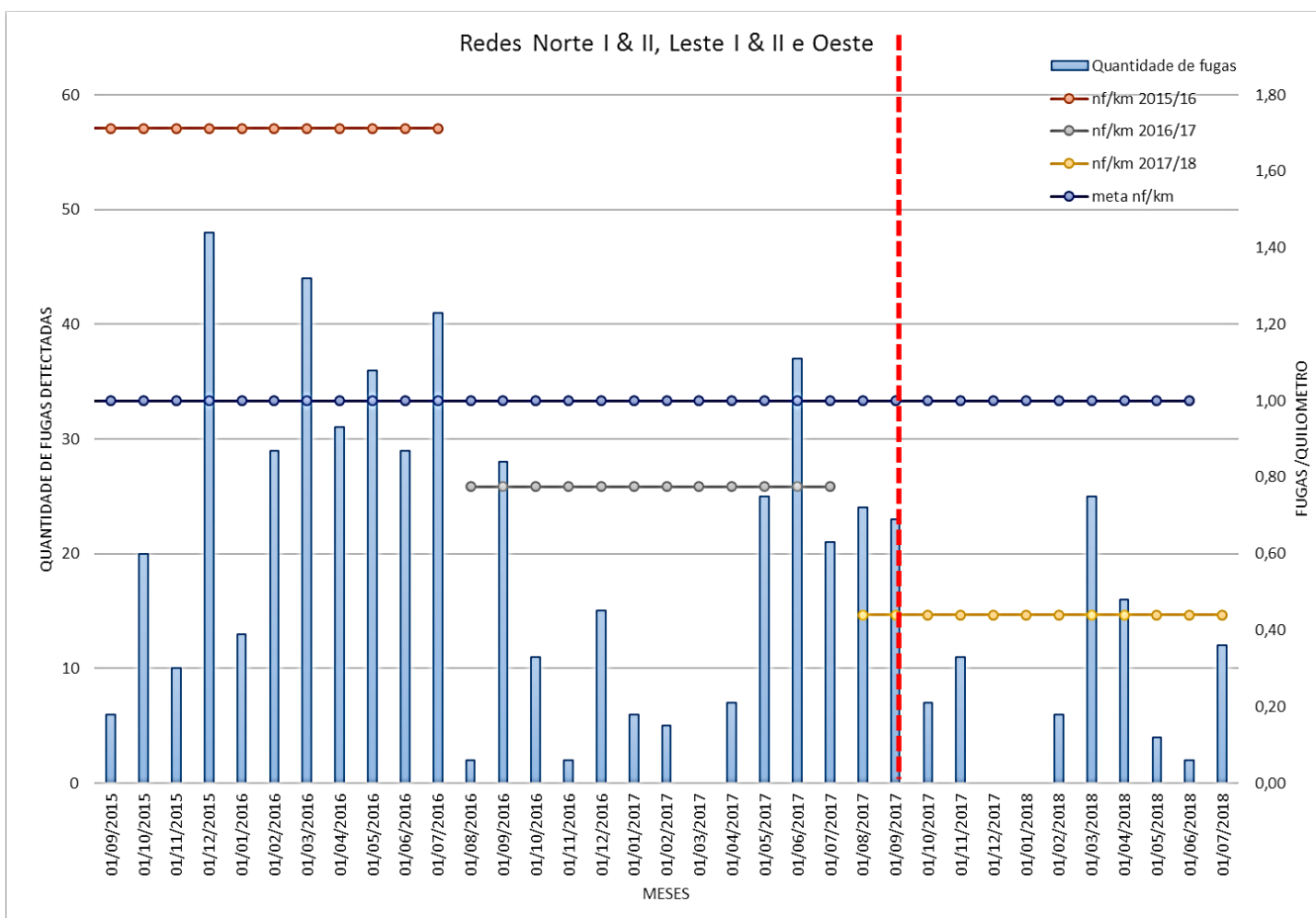

Fonte: Elaborada pelo autor.

A tabela 13 apresenta um resumo da quantidade de fugas detectadas entre os períodos de 2016/2017 (12 meses) até 2017/2018 (12 meses) e custo associado a essa atividade. Com base na tabela 12, observamos que se obteve uma economia efetiva de 935 mil reais após a implantação do SAP PM, o que representa cerca de $2,83 \%$ do orçamento total da manutenção previsto para o ano de 2018.

Tabela 13 - Custo de localização e reparação de fugas na rede estimado

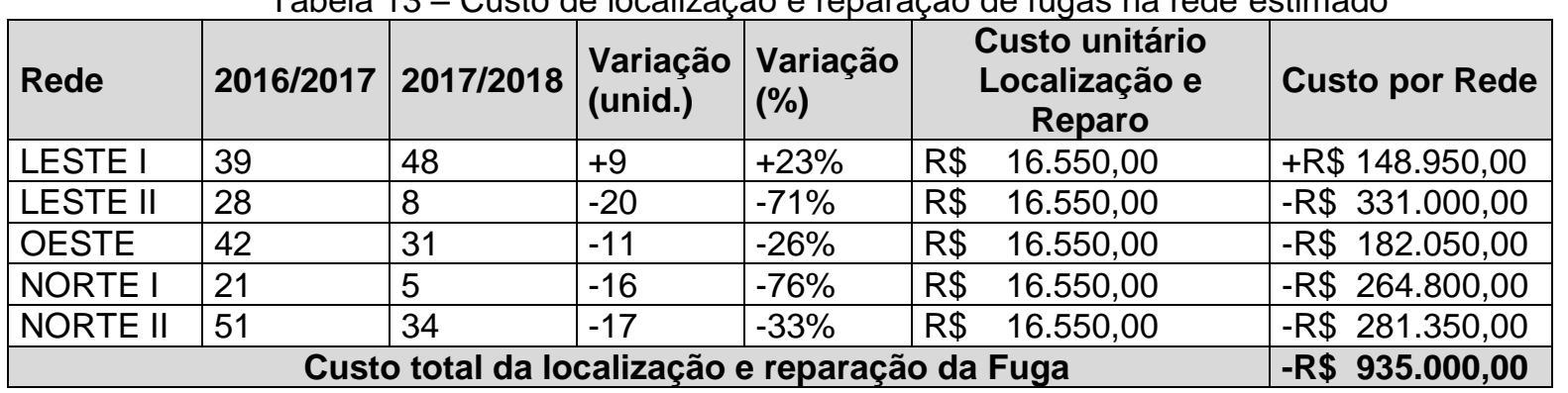

Fonte: Elaborada pelo autor. 


\section{CONSIDERAÇÕES FINAIS}

Concluímos que, para o sistema de distribuição de gás natural operar com o índice de disponibilidade aceitável, ele necessita de intervenções de manutenção de caráter preventivo regular e corretivo quando necessário, não só nas redes de distribuição e transporte, mas também nos equipamentos auxiliares de rede. O processo de detecção de escapamento é de extrema importância para manter o controle da estanqueidade da rede dentro dos patamares operacionais aceitáveis, evitando que avarias causadas por danos nos gasodutos possam ter grandes proporções que comprometam o fornecimento de gás natural ou coloquem em risco a segurança das pessoas e dos operadores que atuam na rede.

Para garantir o controle da manutenção desses ativos de forma sistêmica em uma empresa de grande porte como a GBM, foi necessária a utilização de um sistema baseado em plataforma ERP para consolidação das informações de rede de distribuição, garantindo assim a uniformidade da informação a todos os empregados e melhorando os processos internos para que os gestores da manutenção tenham um controle de todo o sistema.

Criaram-se, por meio dos procedimentos e normas internas da GBM, os planos de manutenção, com o objetivo de manter os ativos seguros através das visitas preventivas e eventuais desdobramentos de ações corretivas, formando uma base de dados históricos sólida e possibilitando a realização de futuros estudos de análise crítica e confiabilidade relacionados à operação das redes de gás natural. Os planos de manutenção criados foram registrados no SAP e, portanto, não podem ser apagados. Cada código cadastrado no software é biunívoco, ou seja, não há possibilidade de encontrar duplicidade de códigos, garantindo assim a confiabilidade e qualidade de todo o processo.

O estudo mostrou que com informação e organização apropriadas é possível gerenciar um sistema de distribuição de gás natural complexo, tornando-o mais eficiente. Dessa forma, evita-se tomadas de decisões equivocadas, consequentemente reduzindo seus custos operacionais, já que pareceres errados podem gerar grandes prejuízos econômicos para a empresa.

Assim sendo, verifica-se que o estudo atingiu as metas almejadas. 


\section{REFERÊNCIAS BIBLIOGRÁFICAS}

[1] MONTEIRO, Jorge Venâncio de Freitas - Gás natural aplicado à indústria e ao grande comércio - São Paulo: Blucher: Comgas, 2010.

[2] AUTOR, 2018

[3] ABNT-NBR 15590 - Regulador de pressão para gases combustíveis. Rio de Janeiro, 2008.

[4] DONIELETTO, José Roberto B. Manual de tubulações de polietileno e polipropileno: características, dimensionamento e instalação. Incluído tubos estruturados, tubos PA 12 e dados sobre outros materiais: PEX, PERT, PB, PVDF, PVC - $3^{a}$ ed. - São Paulo, Linha Aberta, 2014.

[5] DUTRA, A. C.; NUNES, L. de P. Proteção catódica: técnicas de combate à corrosão - 4⿳亠丷a edição - Rio de Janeiro, Interciência, 2016.

[6] GOMES, Luiz Paulo. Sistemas de Proteção Catódica: IECInstalações e Engenharia de Corrosão Ltda. - Rio de Janeiro, 2004.

[7] TELLES, Pedro Carlos da Silva. Tubulações industriais: Materiais, projeto e desenho $-7^{\text {a }}$ ed. - Rio de Janeiro: LTC - Livros técnicos e científicos LTDA, 1987.

[8] PINTO, Alan Kardec; XAVIER, Júlio Nassif. Manutenção: função estratégica. Rio de Janeiro: Qualitymark,1998.

[9] ABNT-NBR 12712 - Projeto de sistemas de transmissão e distribuição de gás combustível, Rio de Janeiro: 2002.

[10] PADOVEZE, Clóvis Luis. Contabilidade gerencial: um enfoque em sistema de informação contábil. São Paulo: Atlas, 2010.

[11] STRASSBURG, Udo. A contabilidade frente aos avanços tecnológicos. Cascavel: EDUNIOESTE, 2004.

[12] CRUZ, Tadeu. Sistemas de informações gerenciais - tecnologia da informação e a empresa do século XXI. $2^{\underline{a}}$ ed., São Paulo: Atlas, 2000.

[13] ALECRIM, Emerson. O que é Tecnologia da Informação (TI). Artigo encontrado na WEB em http://www.infowester.com/ti.php. Acessado em 01/12/2018.

[14] DRUCKER, Peter, Desafios Gerenciais para o século XXI, São Paulo: Pioneira Thomson Learning, 2001. 
[15] MCGEE, J. e PRUSAK, L. Gerenciamento estratégico da informação: aumente a competitividade e a eficiência de sua empresa utilizando a informação como uma ferramenta estratégica. $5^{\text {a }}$ ed. Tradução de Astrid Beatriz de Figueiredo. Rio de Janeiro: Campus, 1994. [16] REZENDE, Denis Alcides; ABREU, Aline França de. Tecnologia da Informação aplicada a sistemas de informação empresariais: o papel Estratégico da informação e dos sistemas de informação nas empresas. 4 a . ed. São Paulo: Atlas, 2006. 